\title{
Early Proterozoic magmatism in Yukon, Canada: constraints on the evolution of northwestern Laurentia ${ }^{1}$
}

\author{
Derek J. Thorkelson, James K. Mortensen, Robert A. Creaser, Garry J. Davidson, \\ and J. Grant Abbott
}

\begin{abstract}
Northwestern Laurentia, after cratonization at about $1.85 \mathrm{Ga}$, underwent a series of tectonic and magmatic events during the Proterozoic that were followed by separation of Laurentia from another landmass, probably Australia. The oldest magmatic event produced the Bonnet Plume River Intrusions (BPRI), which intruded the Wernecke Supergroup as short dikes and small stocks. The BPRI are hydrothermally altered tholeiitic diorites, gabbros, and subordinate anorthositic and syenitic rocks, with trace element signatures consistent with a rift origin. Depleted mantle model ages range from 2.29 to $2.57 \mathrm{Ga}$ and $\varepsilon_{\mathrm{Nd}}$ values range from +0.7 to -1.7 . An increasing crustal component is apparent in rocks with more evolved compositions. Four U-Pb zircon ages (1705.9 \pm 0.7, $1709.4 \pm 1.4,1711.1 \pm 5.1$, and $1713.6 \pm 12.7 \mathrm{Ma}$ ) indicate a Paleoproterozoic age for the BPRI. These dates constrain the age of the Wernecke Supergroup to $\geq$ ca. $1710 \mathrm{Ma}$, making it the oldest supracrustal succession in western Laurentia, e.g., >240 Ma older than the Belt Supergroup of southeastern British Columbia and the northwestern United States. The Wernecke Supergroup was deposited in the first rift basin to open along the western margin of Laurentia, but was later inverted by the pre-1.6 Ga Racklan Orogeny, an event possibly influenced by transmission of compression from the Yavapai and Mazatzal orogenies in southern Laurentia. The Neoproterozoic southwestern United States - east Antarctica (SWEAT) reconstruction, which places Australia next to northwestern Laurentia, is supported by linkages between Paleoproterozoic and Mesoproterozoic geological features in northwestern Canada and Australia.
\end{abstract}

Résumé : Après une cratonisation vers $1,85 \mathrm{Ga}$, le nord-ouest du continent laurentien (Laurentia) a subi une série d'événements tectoniques et magmatiques au cours du Protérozoïque; ces événements ont été suivis par la séparation de Laurentia d'une autre masse continentale, probablement l'Australie. L'événement magmatique le plus ancien a produit les intrusions de la rivière Bonnet Plume (BPRI) qui ont pénétré le Supergroupe de Wernacke en tant que de courts dykes et de petits massifs intrusifs. Les BPRI consistent en des diorites tholéiitiques, des gabbros et des roches subordonnées anorthositiques et syénitiques qui ont subi une altération hydrothermale, avec des signatures d'éléments traces qui concordent avec une origine de fosse. La plage pour les modèles de manteau appauvri varie de 2,29 à 2,57 $\mathrm{Ga}$ et les valeurs $\varepsilon_{\mathrm{Nd}}$ varient de $+0,7$ à $-1,7$. Une plus grande composante crustale est apparente dans les roches avec des compositions plus évoluées. Quatre déterminations d'âge U-Pb sur des zircons donnent un âge paléoprotérozoïque pour les BPRI : 1705,9 \pm 0,7 Ma, 1709,4 \pm 1,4 Ma , 1711,1 \pm 5,1 Ma et 1713,6 \pm 12,7 Ma. Ces dates limitent l'âge du Supergroupe de Wernecke à environ $\geq 1710 \mathrm{Ma}$, faisant de la séquence supracrustale la plus ancienne du Laurentia occidental, par ex., > 240 Ma plus ancien que le Supergroupe de Belt du sud-est de la Colombie-Britannique et du nord-ouest des États-Unis. Le Supergroupe de Wernecke a été déposé dans le premier bassin de distension qui s'est ouvert le long de la limite ouest de Laurentia mais il a été par la suite inversé par l'orogène de Racklan pré-1,6 Ga, un événement possiblement influencé par la transmission de la compression des orogènes Yavapai et Mazatzal dans le sud du Laurentia. La reconstruction du transect sud-ouest américain - est de l'Antarctique (SWEAT), au Néoprotérozoïque, qui place l'Australie à côté du nord-ouest de Laurentia, est appuyé par des liens entre les caractéristiques géologiques Paléo- et Méso- protérozoïques au nord-ouest du Canada et en Australie.

[Traduit par la Rédaction]

Received September 28, 2000. Accepted April 10, 2001. Published on the NRC Research Press Web site at http://cjes.nrc.ca on October 12, 2001.

Paper handled by Associate Editor M.R. St-Onge.

D.J. Thorkelson. ${ }^{2}$ Department of Earth Sciences, Simon Fraser University, Burnaby, BC V5A 1S6, Canada.

J.K. Mortensen. Department of Earth and Ocean Sciences, University of British Columbia, Vancouver, BC V6T 2B4, Canada.

R.A. Creaser. Department of Earth and Atmospheric Sciences, University of Alberta, Edmonton, AB T6G 2E3, Canada.

G.J. Davidson. Centre for Ore Deposit Research, University of Tasmania, GPO Box 252-79, Hobart, Tasmania, Australia, 7001.

J.G. Abbott. Yukon Geology Program, Whitehorse, YT Y1A 2C6, Canada.

${ }^{1}$ Contribution to the International Geological Correlation Program, Projects 400 and 440; Lithoprobe Publication 1216.

${ }^{2}$ Corresponding author (e-mail: dthorkel@sfu.ca). 


\section{Introduction}

More than one quarter of Earth history passed between the time of cratonization in western Canada ( $1850 \mathrm{Ma}$; Hoffman 1989; Villeneuve et al. 1991; Ross et al. 1991) and inception of the Neoproterozoic-Paleozoic Cordilleran miogeocline ( 600 Ma; Gabrielse 1967; Young et al. 1979; Aitken and McMechan 1992; Gabrielse and Campbell 1992). During this interval, the Proterozoic landmass of ancestral North America, commonly referred to as Laurentia, underwent a series of extensional events along its western edge which ultimately led to its separation from another landmass, arguably Australia coupled with east Antarctica (Bell and Jefferson 1987; Moores 1991; Dalziel 1991, 1997; Ross et al. 1992), although Siberia (Sears and Price 1978, 2000) and south China (Li et al. 1995) have also been proposed. Prior to separation, Laurentia was part of one or more proposed supercontinents, namely Arctica, Nena, Kanatia, and Rodinia (Hoffman 1989; Young 1995; Rogers 1996). Configurations and nomenclature for these proposed continental regions are still evolving (e.g., Karlstrom et al. 1999; Burrett and Berry 2000; Sears and Price 2000). The divergence of Laurentia from the other parts of the proposed supercontinents occurred through discrete rift events that affected different parts of western Laurentia at different times, producing basins that filled with successions of clastic and carbonate rocks up to $20 \mathrm{~km}$ thick (Aitken and McMechan 1992; Gabrielse and Campbell 1992). Extension and sedimentation were punctuated by distinct events of magmatism, contractional deformation, and surges of hydrothermal fluids (Eisbacher 1981; Roots and Thompson 1988; Höy 1989; Ross 1991; Thorkelson et al. 2001).

Progress in unravelling the Paleoproterozoic and Mesoproterozoic history of continental separation has been slow, largely because the rift successions have been difficult to date and correlations among the basins have seldom been demonstrated. Isotopic dating of detrital minerals and igneous rocks have, in recent years, provided first-order constraints on the Paleoproterozoic and Mesoproterozoic evolution of northwestern Laurentia (Ross et al. 1992, 2001; Anderson and Davis 1995; Sears et al. 1998; Rainbird et al. 1997; Ross and Villeneuve 1997; Doughty et al. 1998). In contrast, the Neoproterozoic history of rifting is relatively well understood, with the Windermere Supergroup and correlative strata providing convincing evidence for extension, rift volcanism, rift-margin glaciation, and continental disunion (Ross 1991; Young 1995).

In Yukon Territory, northwestern Canada (Figs. 1, 2), events of magmatism punctuate a complex history of Paleoproterozoic to Neoproterozoic supracrustal evolution. At least four discrete igneous events are recognized, each apparently marking an episode of rifting or intraplate magmatism (Gabrielse 1967; Young et al. 1979; Eisbacher 1981; Roots and Thompson 1988; Abbott 1997; Thorkelson 2000). In this report, we focus on the oldest of the four igneous events, namely emplacement of the Bonnet Plume River Intrusions (Fig. 3). Using isotopic studies, geochemistry, and field relations, we demonstrate how these igneous rocks constrain the timing and causes of Paleoproterozoic rifting and contractional tectonism along the northwestern margin of Laurentia.

\section{Bonnet Plume River Intrusions}

\section{Field relations}

The Bonnet Plume River Intrusions (BPRI) are the oldest known igneous rocks in the Yukon (Figs. 1-3; Thorkelson 2000; Thorkelson et al. 2001). They were emplaced as short dikes and small stocks into sedimentary rock of the Proterozoic Wernecke Supergroup (Delaney 1981; Norris and Dyke 1997; Thorkelson 2000). The largest body is exposed over an area of about $0.2 \mathrm{~km}^{2}$. Some of the BPRI retain their original intrusive contacts. However, most of the BPRI were engulfed and fragmented during hydrothermal-phreatic activity, which produced numerous, widespread breccia zones termed Wernecke Breccia (Laznicka and Edwards 1979; Bell 1986; Laznicka and Gaboury 1988), recently dated at ca. 1.6 Ga (Fig. 3; Thorkelson et al. 2001). Most of the BPRI, therefore, occur as metasomatized clasts and enclaves within zones of Wernecke Breccia (Laznicka and Edwards 1979; Laznicka and Gaboury 1988; Thorkelson et al. 2001). Clast and enclave sizes vary from a few millimetres to hundreds of metres in length.

The BPRI are abundant in the Wernecke Mountains of northeastern Yukon, where they have been examined and sampled in conjunction with a recent $1: 50000$ scale mapping program (Figs. 1, 2; Thorkelson 2000). The intrusions, and the breccias which commonly crosscut them, are scattered throughout the area of recent mapping. During brecciation, many intrusions were fragmented, and their clasts were separated from one another by tens or perhaps hundreds of metres by breccia flow and (or) foundering. As a result, the number of discrete, original intrusions is difficult to determine, but is certainly $>20$ and possibly $>100$. The BPRI are locally concentrated in the vicinity of normal faults that may record, at least in part, extensional faulting broadly concurrent with magmatism. Dikes of similar appearance and field relations occur elsewhere in the Wernecke Mountains and in the Ogilvie Mountains of northcentral and northwestern Yukon (Fig. 1), but their ages have not yet been determined.

The BPRI may be correlative with the Slab volcanics, a succession of thin lava flows of mafic to intermediate composition (Fig. 3; Thorkelson 2000). The succession is preserved as a downdropped megaclast (250 m thick) within Wernecke Breccia and was apparently derived from localized foundering of a Proterozoic shield volcano that overlay the Wernecke Supergroup (Thorkelson 2000; Thorkelson et al. 2001).

\section{Petrology and geochemistry}

Nearly all of the BPRI are composed of fine- to mediumgrained diorite and gabbro. Coarse-grained segregations with interstitial quartz are abundant in some of the dioritic bodies. Intrusions of other compositions include quartz albite syenite (one stock) and fine-grained anorthosite (a few megaclasts in Wernecke Breccia). Primary mineralogy of the dioritic bodies is dominated by plagioclase and clinopyroxene, although regional low-grade metamorphism and metasomatic alteration related to emplacement of Wernecke Breccia have typically altered the mineral assemblage. Commonly, pyroxene has altered to chlorite or actinolite, and plagioclase is pseudomorphed by sericite, 
Fig. 1. Distribution of Paleoproterozoic rocks in the Yukon, northwestern Canada, showing location of detailed study area, Fig. 2.

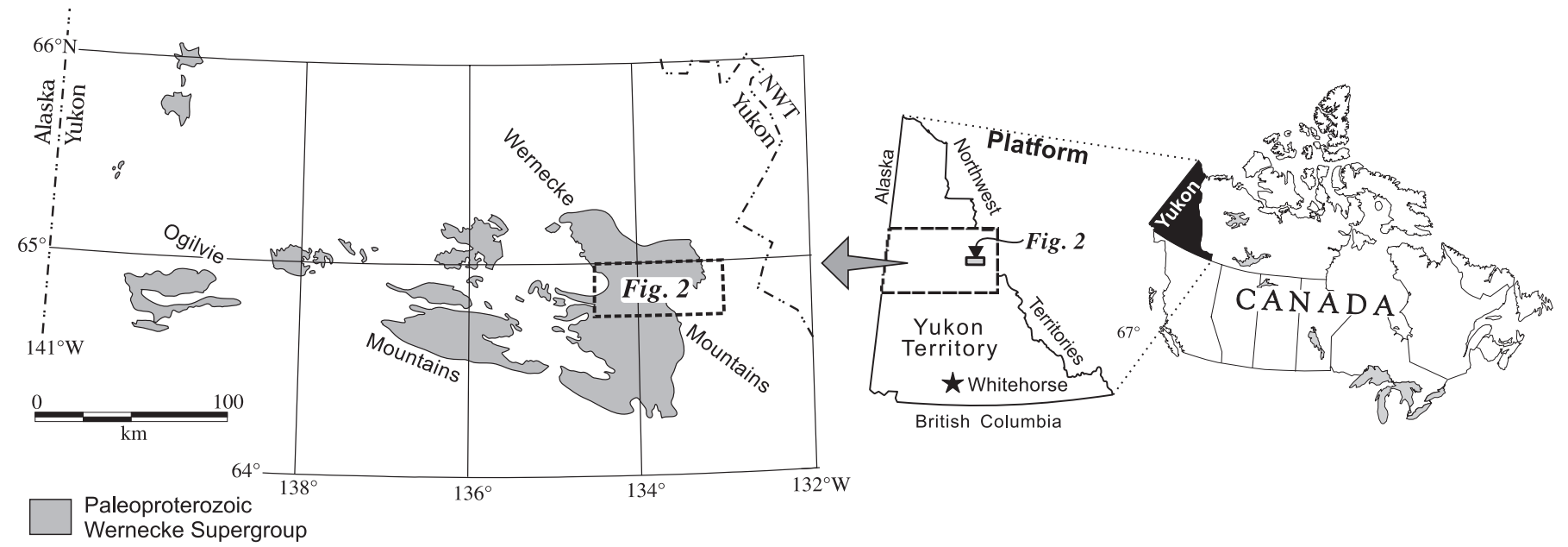

Fig. 2. Simplified geology of the study area (after Thorkelson 2001). The Bonnet Plume River Intrusions (BPRI; ca. 1.71 Ga) are present either as short dikes and small stocks in the Wernecke Supergroup or as megaclasts in zones of younger Wernecke Breccia (ca. 1.6 Ga). Locations of samples 1-5 are provided. The BPRI are too small to be illustrated at this scale.

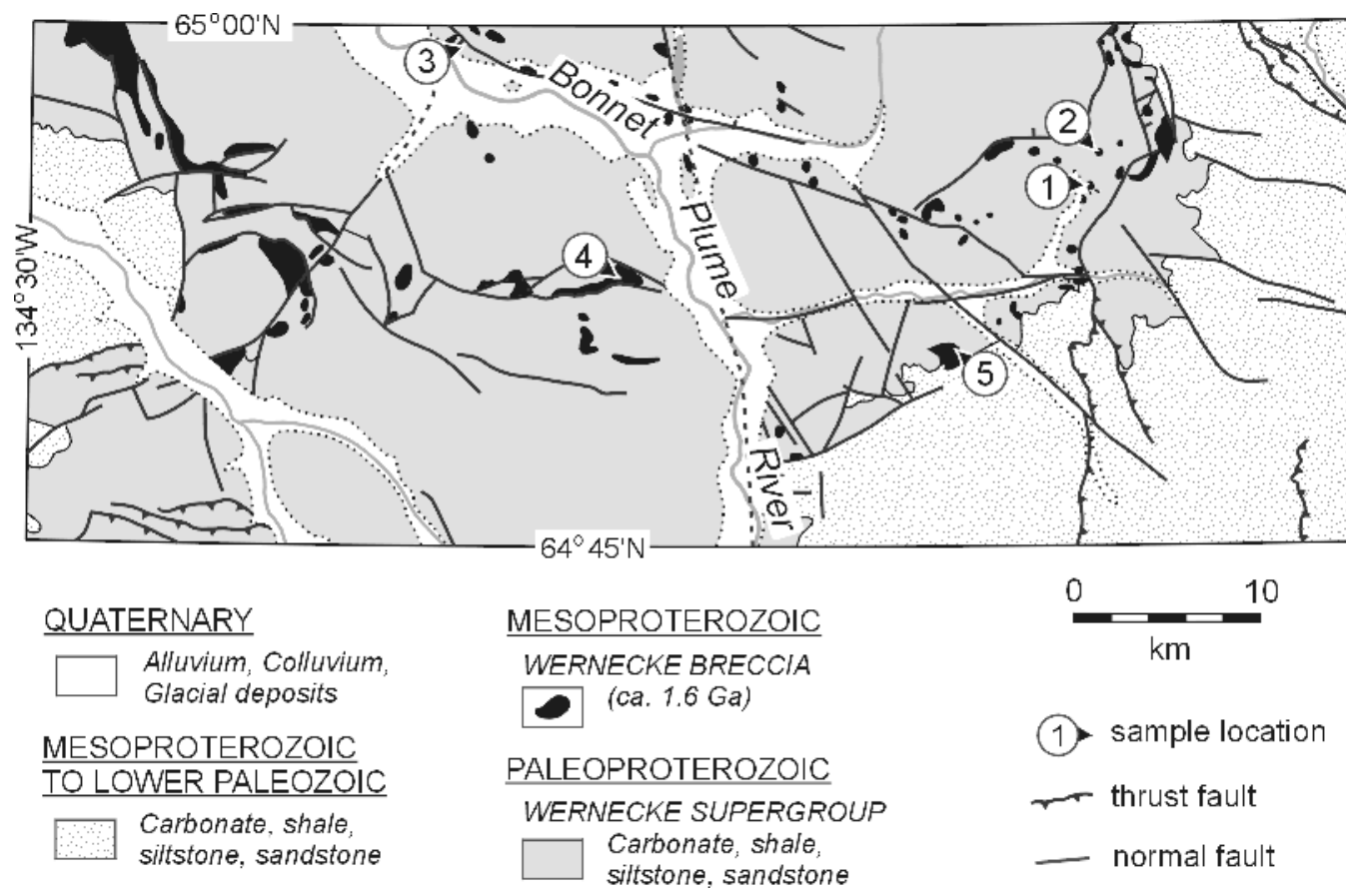

scapolite, and other minerals. Breccia-related fluids have typically introduced hematite as earthy to specular disseminations and veinlets and, less commonly, magnetite as clots or pseudomorphs of plagioclase. Other metasomatic effects include silicification, carbonatization, phyllic to alkali alteration, and precipitation of pyrite and chalcopyrite (Laznicka and Edwards 1979; Laznicka and Gaboury 1988). The sulphide minerals are commonly concentrated along contacts with Wernecke Breccia. Hydrothermal alteration has also affected the syenitic stock by depletion of potassium and addition of sodium, copper, and gold (Laznicka and Edwards 1979).

Twenty-five samples of the BPRI were analyzed by X-ray fluorescence for major oxides and by research-grade inductively coupled mass spectrometry for 40 trace elements. Five selected analyses are provided in Table 1; complete analytical results are provided by Thorkelson (2000). Most of the samples have been affected by hydrothermal activity related to zones of Wernecke Breccia. This metasomatic alteration has largely obscurred the igneous geochemistry of the BPRI, and concentrations of alkali and alkaline earth elements have been particularly affected. When plotted on alkali-silica diagrams, the data are highly scattered and include both subalkalic and alkalic compositions. Using CIPW normative mineralogy, the samples range from highly silica undersaturated (up to $13 \%$ nepheline) to oversaturated $(16 \%$ quartz). Similarly, using molar ratios of alumina and the alkalies, the rocks are variably categorized as metaluminous and peraluminous, although strongly corundum-normative compositions are subordinate. On the $\mathrm{FeO} / \mathrm{MgO}$ versus silica diagram of Miyashiro (1974), the data define a steep iron 
Fig. 3. Time-stratigraphic column of Paleoproterozoic to mid-Mesoproterozoic stratified rocks in the Yukon, showing chronology of depositional, intrusive, and deformational events. The Bonnet Plume River Intrusions (mainly fine-grained diorite) are commonly crosscut by zones of Wernecke Breccia. Correlation of the Slab volcanics with the BPRI is uncertain. Racklan Orogeny occurred prior to emplacement of Wernecke Breccia, but the timing of orogeny relative to emplacement of the BPRI has not been resolved. Ages and field relations are discussed in Thorkelson (2000) and Thorkelson et al. (2001).

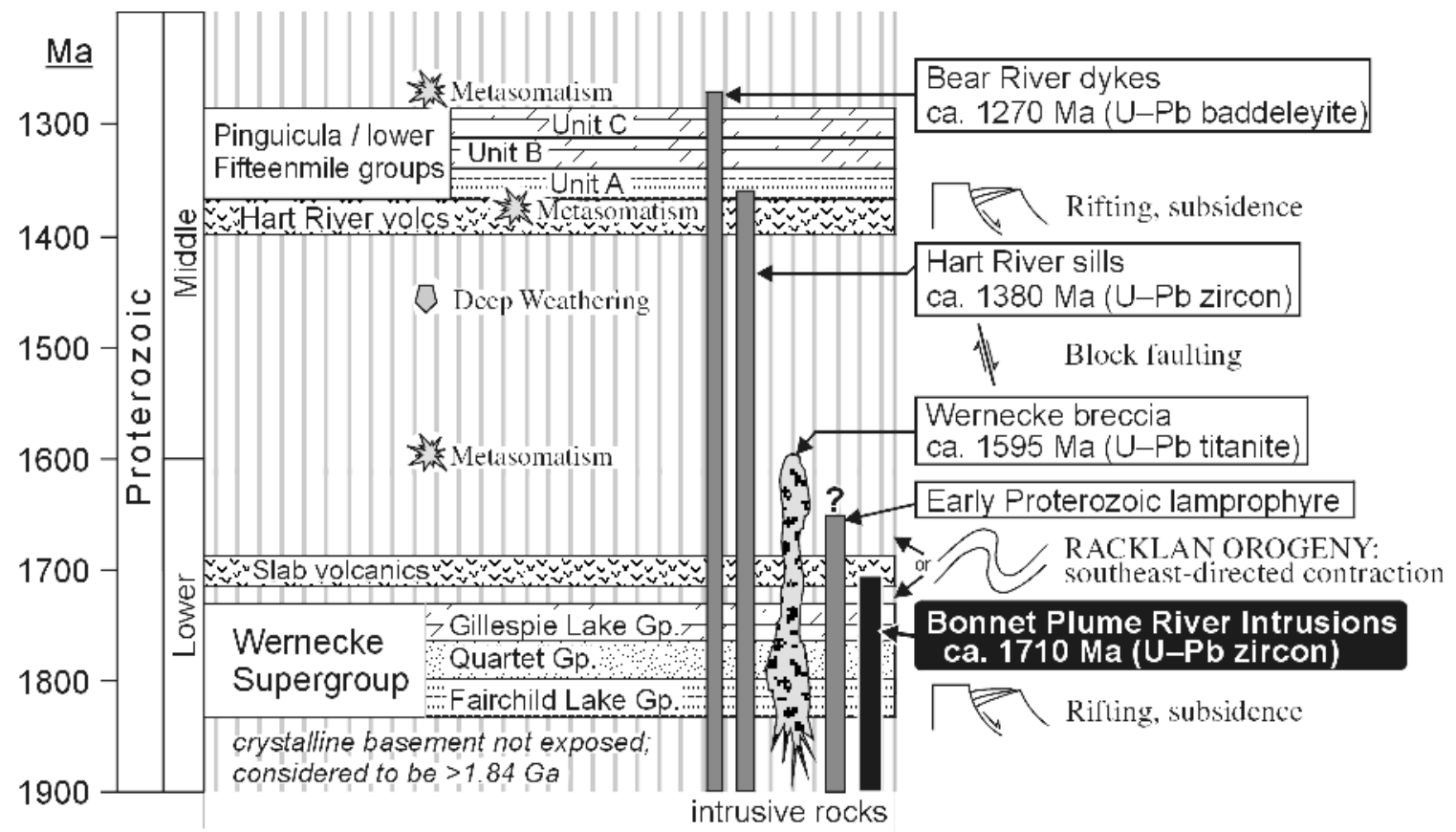

enrichment trend, indicating strong tholeiitic character. The breccia-related fluids, however, are responsible for widespread iron-oxide mineralization, so the degree of iron enrichment may be partly a result of alteration.

Despite the alteration, some aspects of original composition are revealed using elements of relatively low mobility, and values of loss on ignition (LOI), which reflect volatiles removed as part of major oxide analysis. In Fig. $4 a$, profiles of selected high-field strength elements (HFSE), including rare-earth elements (REE), are shown for five samples that were also analyzed for $\mathrm{Sm}-\mathrm{Nd}$ isotopes and (or) dated by $\mathrm{U}-\mathrm{Pb}$. Element concentrations in the profiles have been normalized to normal mid-ocean ridge basalt (N-MORB). These samples are broadly representative of the overall data set. Large-ion lithophile elements (LILE), such as $\mathrm{Ba}, \mathrm{Rb}, \mathrm{U}$, and $\mathrm{Sr}$, have been excluded from the profiles because of greater scatter and a greater probability of hydrothermally induced mobility. Sample 1 is quartz albite syenite, and the others are variably altered diorite and gabbro. The profiles for samples 1-4 display similar patterns, but at different levels of concentration. Th, $\mathrm{Nb}$, and the light REE are consistently enriched over $\mathrm{Zr}$ and the heavy REE. Negative $\mathrm{Zr}$ anomalies are present in samples $1-4$, and negative $\mathrm{Nb}$ anomalies are evident in samples 2 and 4. Slight $\mathrm{Eu}$ anomalies are also present in three of the samples. The profile of sample 5 is markedly different, with a flatter REE pattern and a positive $\mathrm{Zr}$ anomaly. This sample is highly altered and contains abundant specular hematite.

Prior to data interpretation, the issue of open- or closedsystem behaviour of the HFSE is addressed on a logarithmic scale plot of $\mathrm{Zr}$ versus Ce in Fig. $4 b$. In lieu of symbols, data points are shown by values of LOI (wt.\%) for the samples, rounded to the nearest integer. The data points are framed by three lines of constant $\mathrm{Zr} / \mathrm{Ce}$ ratio. All of the samples are from diorite and gabbro, except for three relatively evolved samples of anorthosite, syenite, and a pegmatitic segregation within diorite, whose data points are circled. Three of the four diorite-gabbro samples with lowest LOI values, in the 1-2 range (shown in bold type), have $\mathrm{Zr} / \mathrm{Ce}$ values near 1 . However, another sample with an LOI value of 1 has a $\mathrm{Zr} / \mathrm{Ce}$ ratio of about 3 . A ratio of approximately 10 would yield equal N-MORB normalized values. The more hydrated samples, with LOI > 2, are less reliable indicators of original igneous values and are scattered mainly between $\mathrm{Zr} / \mathrm{Ce}$ ratios of 1 and 4 .

The distribution of the low-LOI data suggests that $\mathrm{Zr} / \mathrm{Ce}$ ratios of approximately 1 are most representative of igneous character, but ratios of up to 3 may also be primary and not generated solely through alteration. Ratios of less than 1 and greater than 3, however, may be a result of element mobility, probably during metasomatism related to Wernecke Breccia generation. In Fig. 4a, samples 2, 3, and 4 have $\mathrm{Zr} / \mathrm{Ce}$ ratios between 1 and 2 and display marked troughs at Zr, which, using the foregoing arguments, are considered ostensibly magmatic in origin. Sample 4 has a $\mathrm{Zr} / \mathrm{Ce}$ ratio of 3.5 and a less pronounced trough. Sample 5, which is the most metasomatized sample and contains abundant specular hematite, has a $\mathrm{Zr} / \mathrm{Ce}$ ratio of 9.3 , displays a peak at $\mathrm{Zr}$, and is regarded as severely metasomatized with remobilized REE.

$\mathrm{Zr}$ and $\mathrm{Ce}$ abundances vary by more than seven times for the range of diorites and gabbros and approximately 20 times for the whole suite (Fig. 4b). Could these variations in abundance have resulted from closed-system evolution from 
Table 1. Geochemical analyses.

\begin{tabular}{|c|c|c|c|c|c|}
\hline Sample No.: & 1 & 2 & 3 & 4 & 5 \\
\hline Field No.: & DT-93-52-1b & DT-94-22-1b & DT-94-20-1b & DT-93-25-1b & DT-93-163-1b \\
\hline Material: & Quartz syenite & Pegmatitic diorite & Gabbro & Diorite (clast) & Hematitic diorite \\
\hline NTS map area: & $106 \mathrm{C} / 14$ & $106 \mathrm{C} / 14$ & $106 \mathrm{D} / 16$ & $106 \mathrm{C} / 13$ & $106 \mathrm{C} / 14$ \\
\hline UTM easting: & 580700 & 508850 & 546200 & 554700 & 573540 \\
\hline UTM northing: & 7200900 & 7202700 & 7208200 & 7194800 & 7191370 \\
\hline $\mathrm{SiO}_{2}$ & 59.1 & 56.8 & 48.6 & 52.2 & 53.6 \\
\hline $\mathrm{TiO}_{2}$ & 2.00 & 2.05 & 2.15 & 0.92 & 2.01 \\
\hline $\mathrm{Al}_{2} \mathrm{O}_{3}$ & 12.1 & 14.3 & 16.7 & 16.8 & 11.4 \\
\hline $\mathrm{FeO}^{*}$ & 12.6 & 10.6 & 8.1 & 11.5 & 21.1 \\
\hline $\mathrm{MnO}$ & 0.07 & 0.16 & 0.22 & 0.19 & 0.13 \\
\hline $\mathrm{MgO}$ & 2.12 & 2.95 & 7.27 & 6.80 & 5.08 \\
\hline $\mathrm{CaO}$ & 5.16 & 5.27 & 12.26 & 6.91 & 1.19 \\
\hline $\mathrm{Na}_{2} \mathrm{O}$ & 6.07 & 6.04 & 3.44 & 2.43 & 0.64 \\
\hline $\mathrm{K}_{2} \mathrm{O}$ & 0.08 & 1.00 & 1.18 & 2.12 & 4.48 \\
\hline $\mathrm{P}_{2} \mathrm{O}_{5}$ & 0.72 & 0.74 & 0.17 & 0.07 & 0.28 \\
\hline LOI & 2.45 & 3.53 & 1.63 & 4.30 & 3.00 \\
\hline Original totals & 98.9 & 97.6 & 97.5 & 99.1 & 100.1 \\
\hline $\mathrm{Li}$ & 6.0 & 12.1 & 17.4 & 27.1 & 39.1 \\
\hline $\mathrm{Be}$ & 0.70 & na & na & 1.75 & 1.55 \\
\hline $\mathrm{Sc}$ & 16.4 & 13.4 & 46.0 & 32.8 & 33.7 \\
\hline V & 27.4 & 104.0 & 216.0 & 269.2 & 636.8 \\
\hline $\mathrm{Rb}$ & 2.5 & 19.7 & 56.1 & 50.9 & 65.4 \\
\hline $\mathrm{Sr}$ & 49.4 & 63.9 & 512.0 & 146.2 & 68.4 \\
\hline $\mathrm{Y}$ & 108.1 & 81.4 & 21.1 & 10.9 & 14.5 \\
\hline $\mathrm{Zr}$ & 508.4 & 282.9 & 46.6 & 18.2 & 68.7 \\
\hline $\mathrm{Nb}$ & 66.0 & 73.5 & 24.2 & 3.2 & 6.4 \\
\hline Cs & 0.18 & 0.74 & 1.70 & 0.76 & 0.59 \\
\hline $\mathrm{Ba}$ & 130.8 & 176.8 & 295.6 & 211.6 & 612.9 \\
\hline $\mathrm{La}$ & 59.5 & 83.3 & 20.7 & 5.2 & 3.4 \\
\hline $\mathrm{Ce}$ & 144.7 & 180.8 & 44.7 & 13.2 & 7.4 \\
\hline $\operatorname{Pr}$ & 19.3 & 20.8 & 5.8 & 1.7 & 1.0 \\
\hline $\mathrm{Nd}$ & 80.8 & 78.6 & 24.4 & 7.7 & 4.0 \\
\hline $\mathrm{Sm}$ & 18.8 & 16.7 & 5.6 & 1.9 & 1.4 \\
\hline Eu & 4.5 & 3.5 & 2.0 & 0.6 & 0.6 \\
\hline Gd & 20.8 & 15.6 & 5.4 & 2.4 & 2.3 \\
\hline $\mathrm{Tb}$ & 3.2 & 2.5 & 0.8 & 0.4 & 0.4 \\
\hline Dy & 21.2 & 15.4 & 4.5 & 2.6 & 2.8 \\
\hline Но & 4.3 & 3.2 & 0.9 & 0.6 & 0.6 \\
\hline $\mathrm{Er}$ & 12.7 & 9.2 & 2.3 & 1.6 & 1.6 \\
\hline $\mathrm{Tm}$ & 1.9 & 1.3 & 0.3 & 0.2 & 0.2 \\
\hline $\mathrm{Yb}$ & 12.1 & 8.0 & 1.8 & 1.5 & 1.4 \\
\hline $\mathrm{Lu}$ & 1.9 & 1.0 & 0.3 & 0.2 & 0.2 \\
\hline Hf & 13.3 & 6.7 & 2.0 & 0.8 & 2.0 \\
\hline $\mathrm{Ta}$ & 4.0 & 4.6 & 1.3 & 0.3 & 0.4 \\
\hline $\mathrm{Tl}$ & 0.00 & 0.09 & 0.11 & 0.14 & 0.36 \\
\hline $\mathrm{Pb}$ & 6.3 & 7.0 & 6.5 & 1.8 & 2.8 \\
\hline $\mathrm{Bi}$ & 0.22 & 0.22 & 0.08 & 0.15 & 0.08 \\
\hline Th & 34.5 & 49.8 & 2.5 & 0.8 & 2.3 \\
\hline $\mathrm{U}$ & 5.93 & 4.20 & 0.52 & 0.29 & 0.79 \\
\hline $\mathrm{Cr}$ & 49 & 12 & 165 & 490 & 59 \\
\hline Co & 39 & 33 & 32 & 47 & 34 \\
\hline $\mathrm{Ni}$ & 2.2 & 10.0 & 75.0 & 68.0 & 37.2 \\
\hline $\mathrm{Cu}$ & 2124.0 & na & na & 14.0 & 37.3 \\
\hline $\mathrm{Zn}$ & 53.6 & 114.0 & 52.0 & 51.1 & 62.0 \\
\hline $\mathrm{Ag}$ & 2.70 & na & na & 0.03 & 0.74 \\
\hline Sn & 3.1 & na & na & 1.1 & 2.1 \\
\hline $\mathrm{Sb}$ & 0.54 & na & na & 4.27 & 2.50 \\
\hline
\end{tabular}

Note: Sample locations are indicated in Fig. 2. Major oxides are in wt.\%, volatile-free, and trace elements in ppm. FeO*, total Fe as FeO; LOI, loss on ignition (as reported in original total); na, not analyzed; NTS, National Topographic System; UTM, Universal transverse Mercator coordinates; Original total, all oxides plus LOI as reported by the laboratory. Analyses for additional BPRI samples are provided in Thorkelson (2000).

a common parental magma? The answer is no, on the basis of Rayleigh fractionation (mineral surface equilibrium) modeling displayed in Fig. $4 b$. The two-headed vector shows the concentrations of $\mathrm{Ce}$ and $\mathrm{Zr}$ that would result from fractionation of a parental magma with initial abundances toward the low end of the data range. The positions of the arrowheads indicate the abundances that would be generated from $25 \%$ (short arrow) and $50 \%$ fractional crystallization (long arrow), under conditions of perfect incompatibility of $\mathrm{Zr}$ and $\mathrm{Ce}$ with fractionating phases (i.e., mineral/melt parti- 
Fig. 4. Geochemical and isotopic characteristics of the BPRI. (a) N-MORB-normalized trace element profiles, $\varepsilon_{\mathrm{Nd}}(T)$, U-Pb ages, LOI (wt.\% loss on ignition), and $\mathrm{Zr} / \mathrm{Ce}$ ratios. Sample 5 has been highly altered. (b) $\mathrm{Zr}-\mathrm{Ce}$ diagram, in which data points are indicated by LOI values, rounded to the nearest whole number. Data points in circles are from relatively evolved rocks (syenite, anorthosite, and a pegmatitic segregation in diorite); all other data are from diorite and gabbro. LOI values of 1 and 2 are shown in bold for emphasis. Vectors show the maximum amounts that $\mathrm{Ce}$ and $\mathrm{Zr}$ concentrations would rise after $25 \%$ (short vector) and 50\% (long vector) closedsystem Rayleigh fractionation, by assuming complete incompatibility with fractionating phases.

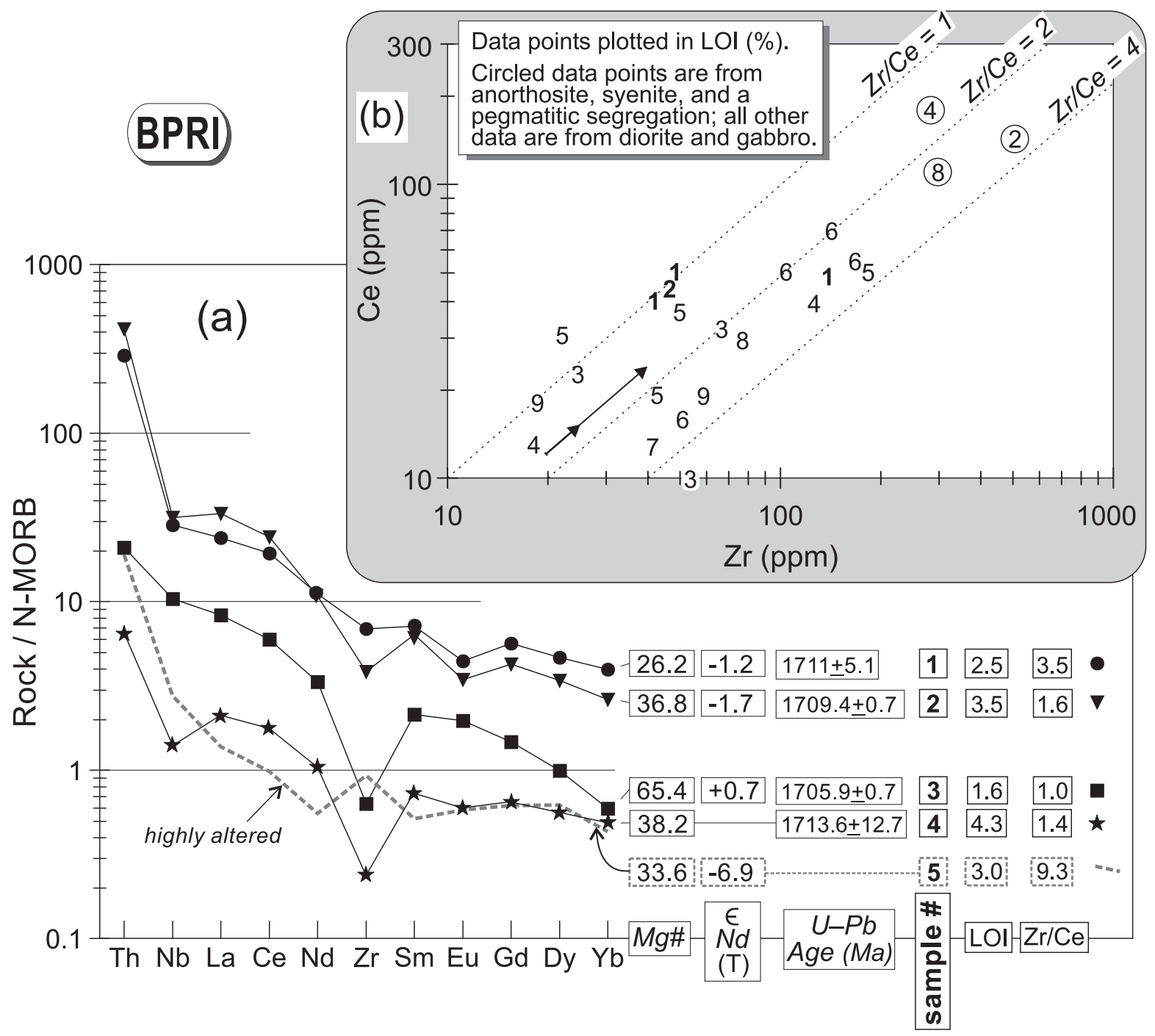

tion coefficients $<<1$ ). The resultant model values represent the highest possible $\mathrm{Ce}$ and $\mathrm{Zr}$ concentrations for closedsystem behavior at $25 \%$ and $50 \%$ fractionation. A similar model using compatible elements $(\mathrm{Sc}, \mathrm{Ni}, \mathrm{Cr}$ ) indicated that fractionation could not have reached $50 \%$ and was probably limited to approximately $25 \%$. Since the vectors in the $\mathrm{Zr}-$ Ce diagram extend less than half of the way along the range of data, closed-system igneous behavior is effectively ruled out. Furthermore, the range in $\mathrm{Zr} / \mathrm{Ce}$ observed in the data set cannot be accommodated by fractional crystallization without invoking highly variable partition coefficients for $\mathrm{Ce}$ and $\mathrm{Zr}$. Consequently, genesis of the BPRI must have involved one or more open-system attributes, such as variable compositions of primary magmas, assimilation of crustal or mantle wall rock, and metasomatic alteration.

Some preliminary observations regarding tectonic environment and source rock are tendered, despite uncertainties regarding the nature and degree of open-system processes as revealed by the $\mathrm{Zr}$ and $\mathrm{Ce}$ systematics. Most of the BPRI have steep down-to-the-right trace-element profiles with modest depletions at $\mathrm{Nb}$ and $\mathrm{Zr}$ (Fig. $4 a$ ) and resemble other Proterozoic dike swarms (Smith 1992; Tarney 1992) and crustally contaminated continental flood basalts of Phanerozoic age (e.g., Thompson et al. 1984). The tectonic affinity of the BPRI is further explored in Fig. 5, which utilizes pairs of the well-known $\mathrm{La} / \mathrm{Th}, \mathrm{La} / \mathrm{Ba}$, and $\mathrm{Nb} / \mathrm{La}$ discriminant ratios of Gill (1981) and the Ti/V ratio of Shervais (1982). As in Fig. 4b, data points are plotted using weight percent LOI. In the $\mathrm{La} / \mathrm{Th}$ versus $\mathrm{La} / \mathrm{Ba}$ diagram (Fig. 5a), which evaluates enrichments of LILE, most of the diorite and gabbro samples plot in or near the correlated arc field. The three least hydrated samples (LOI < 2) are surprisingly scattered in their $\mathrm{La} / \mathrm{Ba}$ ratios, possibly due to $\mathrm{Ba}$ mobility, although they have consistently arc-like $\mathrm{La} / \mathrm{Th}$ ratios. 
Fig. 5. Bivariate plots using elemental ratios for distinguishing tectonic affinity (ratios after Gill 1981, except for Ti/V from Shervais 1982). Data points are indicated by values of LOI, as described in Fig. 4b. Shaded fields show where ratios on both axes have the same tectonic affinity. Three data points in $a$ and one point in $b$ have values beyond the ranges of the diagrams and are not shown.
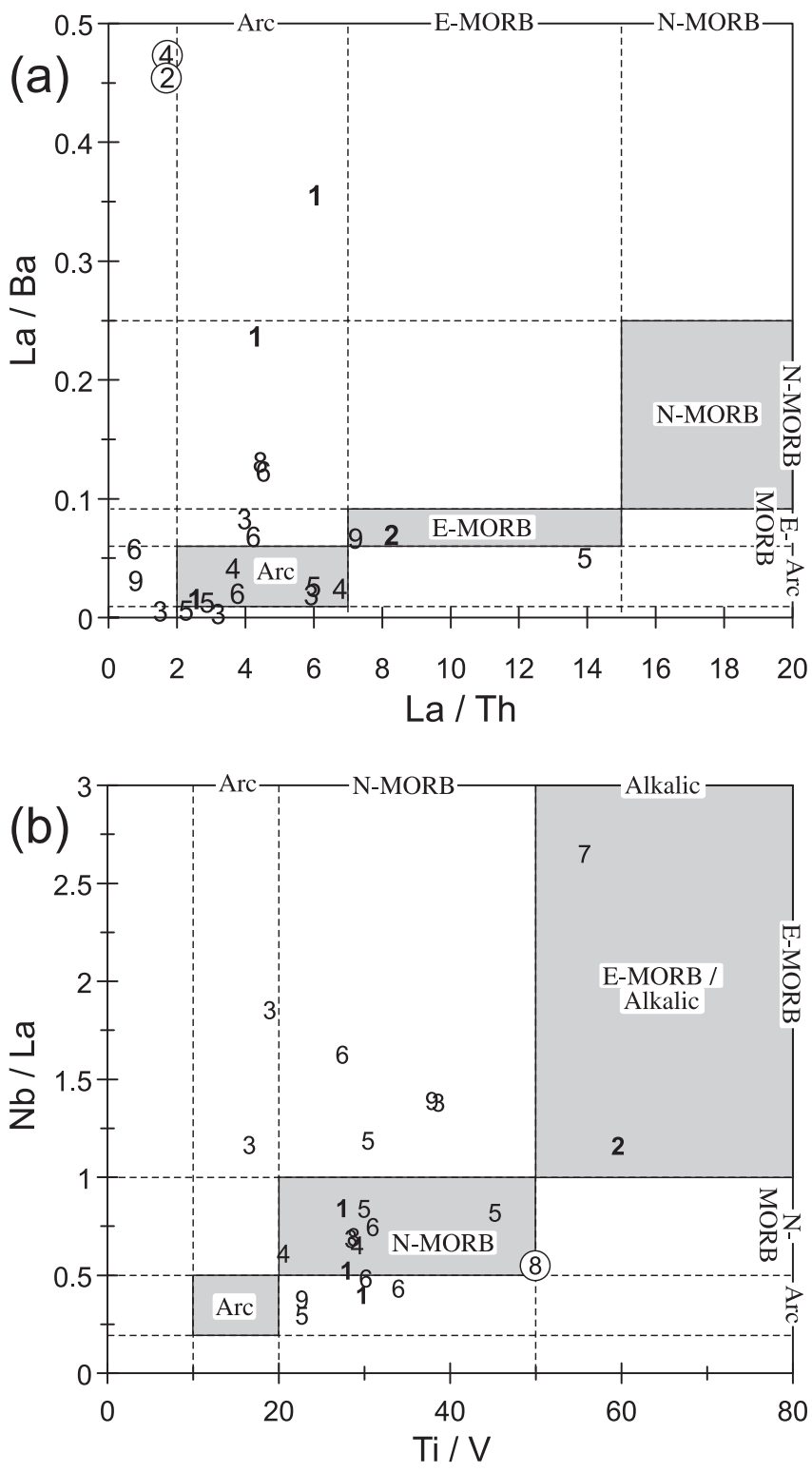

Overall, this diagram indicates that the BPRI have a significant degree of LILE enrichment, which may reflect various processes, including genesis in a subduction environment, assimilation of continental crust, or low degrees of partial melting. Refinement of tectonic affinity is revealed in the $\mathrm{Ti} / \mathrm{V}$ versus $\mathrm{Nb} / \mathrm{La}$ diagram (Fig. $5 b$ ), which uses ratios that are arguably better suited for determining the degree of "arc character." The three samples with lowest LOI plot in or near the correlated N-MORB field. The remaining samples show considerable scatter, but none plot in the correlated arc field and only two plot in the field of enriched-MORB (EMORB) and alkalic rocks. Taken together, the data suggest that the BPRI were generated from mantle similar to that involved in genesis of normal Mesozoic and Cenozoic sea floor. The steepness of the profiles and the LILE enrichment, are most plausibly explained by relatively small degrees of mantle anatexis possibly coupled with crustal assimilation. Genesis in an extensional continental environment is favoured and is consistent with the predominance of diorite and gabbro, with minor syenite and anorthosite. Anatexis of enriched plume-like mantle with high abundances of $\mathrm{Nb}$ and Ta relative to the REE and LILE is not indicated.

$\mathrm{Sm}-\mathrm{Nd}$ isotopic data for four samples provide additional constraints on the origin of the BPRI (Table 2; Fig. 4a). Samples 1-3 show a range of $\varepsilon_{\mathrm{Nd}}(T)$ values of +0.7 to -1.7 , with depleted mantle model $\left(T_{\mathrm{DM}}\right)$ ages of $2.29-2.57 \mathrm{Ga}$. The $\varepsilon_{\mathrm{Nd}}(T)$ values generally correlate with whole-rock $\mathrm{Mg \#}$ (Fig. 4a). Sample 3, which has the youngest $T_{\mathrm{DM}}$ and highest $\varepsilon_{\mathrm{Nd}}(T)$ value, is geochemically the most primitive, based on the highest $\mathrm{Mg \#}$; highest $\mathrm{Cr}, \mathrm{Ni}$, and $\mathrm{Sc}$ concentrations; and lowest $\mathrm{Nb}, \mathrm{Zr}, \mathrm{REE}$, and $\mathrm{SiO}_{2}$ abundances. Samples 1 and 2 are geochemically more evolved and show higher $T_{\mathrm{DM}}$ ages and lower $\varepsilon_{\mathrm{Nd}}(T)$ values. The trend toward lower $\varepsilon_{\mathrm{Nd}}(T)$ values in geochemically more evolved rocks may be a result of progressive assimilation of crustal rock with negative epsilon values by primitive magma with a positive epsilon value (e.g., similar in composition to sample 3). Sample 5 has an $\varepsilon_{\mathrm{Nd}}(T)$ value of -6.9 , which is attributable to its high degree of alteration and probable remobilization of REE, and its model age is therefore not provided. More detailed petrogenesis of the BPRI will be examined elsewhere.

\section{Geochronology}

Four of the BPRI were dated by the U-Pb method on zircon. Three are intrusions that crosscut the lowest group in the Wernecke Supergroup, the Fairchild Lake Group. The fourth is a megaclast in a large zone of Wernecke Breccia, which lies within the highest group in the Wernecke Supergroup, the Gillespie Lake Group. The interpreted ages are shown in Fig. 2, the map of the study area; in Fig. $4 a$ alongside chemical information; and in Fig. 6 in the $\mathrm{U}-\mathrm{Pb}$ concordia diagrams. Analytical details are provided in Table 3.

Sample 1 is from a small stock $(150 \times 300 \mathrm{~m})$ of finegrained quartz albite syenite that was emplaced into siltstone and dolostone of the Fairchild Lake Group. Although the intrusion has been largely dismembered during emplacement of Wernecke Breccia zones, part of its original intrusive contact is preserved along its eastern side. The intrusion was previously interpreted as metasomatically altered diorite and country rock (Laznicka and Edwards 1979), but more recent field and petrologic studies have revealed its origin as a metasomatized, felsic igneous intrusion (Thorkelson 2000).

Less than $200 \mu \mathrm{g}$ of zircon was recovered from sample 1. It consisted mainly of broken fragments of clear, pale to medium pink, strongly fractured prismatic grains. Four fractions of moderately abraded zircon were analyzed (Table 3 ). U concentrations were high (1458-2722 ppm), and the fractions ranged from 15 to $30 \%$ discordant. The analyses define a linear array (Fig. 6a), however, with a low mean square of the weighted deviates $(\mathrm{MSWD}=0.8)$. Calculated upper and lower intercepts are $1711.1 \pm 5.1$ and $\sim 312 \mathrm{Ma}$, respectively. The upper intercept is interpreted as the crystallization age 
Table 2. Sm-Nd analytical data.

\begin{tabular}{|c|c|c|c|c|c|c|c|c|}
\hline Sample No. & $\mathrm{Sm}(\mathrm{ppm})$ & $\mathrm{Nd}(\mathrm{ppm})$ & ${ }^{147} \mathrm{Sm} /{ }^{144} \mathrm{Nd}$ & ${ }^{143} \mathrm{Nd} /{ }^{144} \mathrm{Nd}^{a}$ & $\pm 2 \mathrm{sm}$ & $\varepsilon_{\mathrm{Nd}}(T)$ & $T_{\mathrm{DM}}$ & $T$ (Ma) \\
\hline 1 & 19.02 & 79.30 & 0.1450 & $0.511997(9)$ & 9 & -1.2 & 2.57 & 1711.14 \\
\hline 2 & 16.73 & 81.51 & 0.1241 & $0.511736(9)$ & 9 & -1.7 & 2.42 & 1709.40 \\
\hline 5 & 1.27 & 3.97 & 0.1932 & $0.512249(19)$ & 19 & -6.9 & - & 1713.60 \\
\hline
\end{tabular}

Note: Methods for Sm-Nd isotopic analysis and model for $T_{\mathrm{DM}}$ calculation outlined in Creaser et al. (1997).

${ }^{a}$ Values in parentheses indicate two standard errors of the mean.

Fig. 6. Concordia diagrams for U-Pb (zircon) age determinations on the BPRI. excl., excluding.
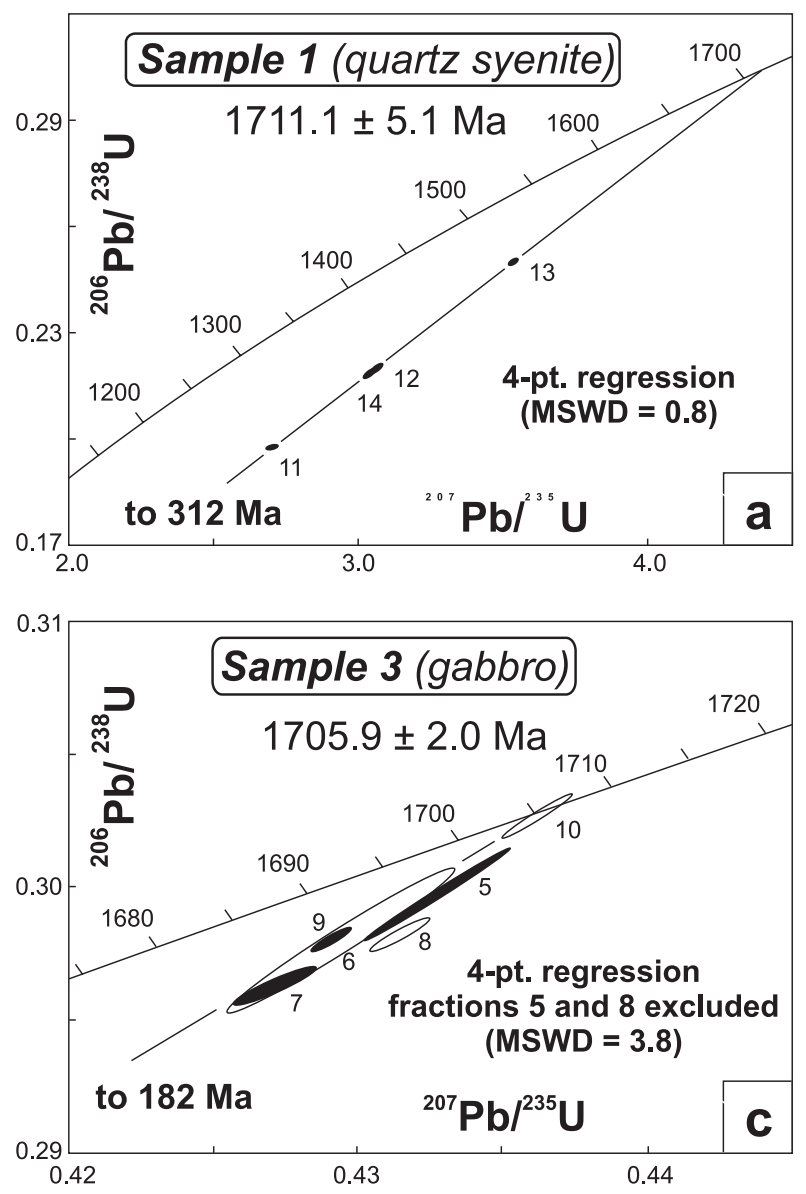

of the sample, and the lower intercept indicates relatively recent $\mathrm{Pb}$ loss.

Sample 2 is from pegmatitic segregations of a fine- to medium-grained diorite dike, which crosscuts the Fairchild Lake Group. The western side of the intrusion has been invaded by Wernecke Breccia, but its eastern intrusive margin remains intact. Zircon in this sample comprised pale to medium pink, stubby, euhedral prisms with simple terminations. The grains contained rare clear inclusions and displayed very faint igneous zoning, but no visible cores. Four fractions were analyzed (Fig. $6 b$; Table 3). Despite the very high $\mathrm{U}$ contents of the zircons (2607-4904 ppm), the grains range from 1.1 to $3.7 \%$ discordant and have, therefore, only experienced relatively minor postcrystallization $\mathrm{Pb}$ loss. The four analyses define a linear array $(\mathrm{MSWD}=2.8)$ with calculated upper and lower intercepts of $1709.0 \pm 1.4$ and $\sim 69 \mathrm{Ma}$, respectively. The upper intercept is interpreted as the
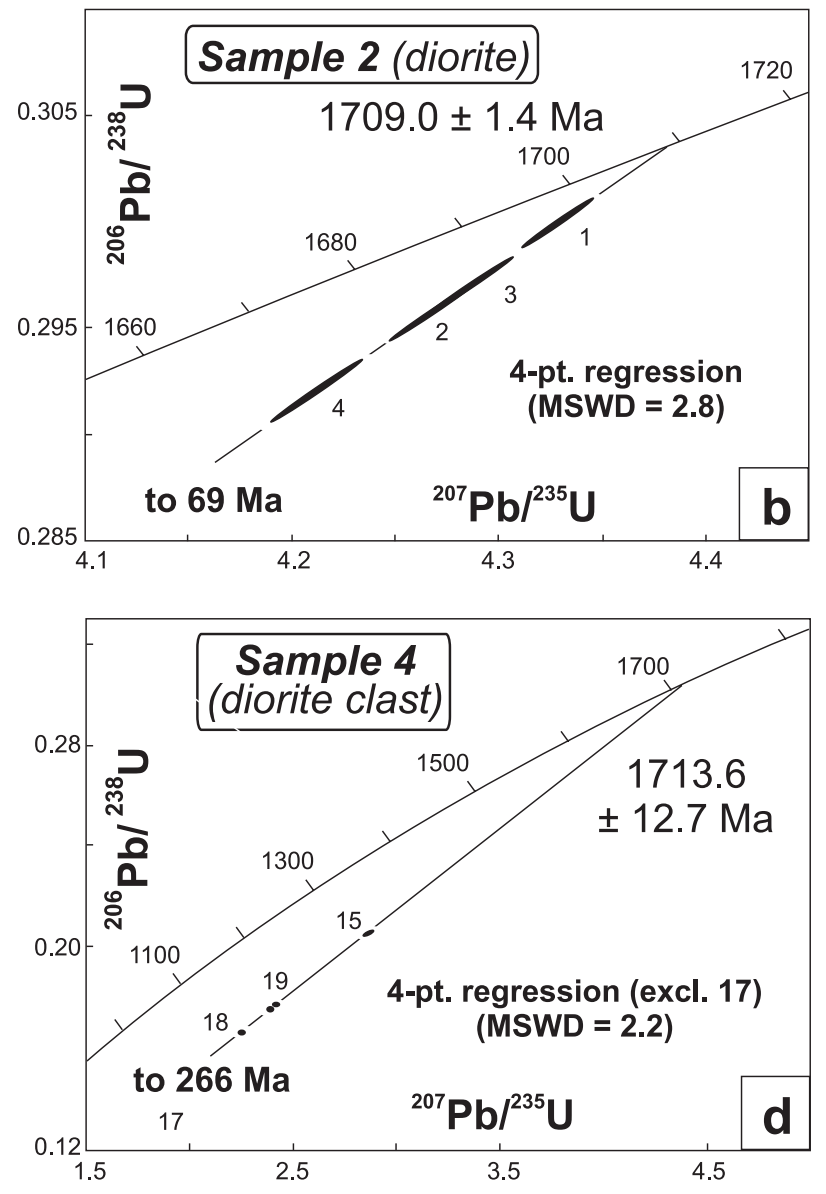

crystallization age of the sample, and the lower intercept indicates that most $\mathrm{Pb}$ loss that affected the grains was relatively recent.

Sample 3 is from a small, medium-grained gabbroic stock within kink-banded phyllite of the Fairchild Lake Group. A zone of Wernecke Breccia adjacent to the stock contains megaclasts of highly altered diorite, which are probably derived from the stock. Initial observations suggest that the stock was emplaced after the formation of the cleavage and kink bands, but additional study is needed to confirm these relations. The deformational events were developed during the Racklan Orogeny (Gabrielse 1967), a period of regional, southeast-directed contraction (Cook 1992), which predated Wernecke Breccia emplacement at ca. 1.6 Ga (Thorkelson et al. 2001).

Zircons recovered from sample 3 were similar in appearance to those from the previous sample. Six strongly abraded 
Table 3. U-Pb analytical data.

\begin{tabular}{|c|c|c|c|c|c|c|c|c|c|c|c|c|}
\hline Fraction & $\begin{array}{l}\text { Sample } \\
\text { description }^{a}\end{array}$ & $\begin{array}{l}\text { Wt. } \\
\text { (mg) }\end{array}$ & $\begin{array}{l}\text { U content } \\
\text { (ppm) }\end{array}$ & $\begin{array}{l}\mathrm{Pb} \text { content } \\
(\mathrm{ppm}){ }^{b}\end{array}$ & $\frac{{ }^{206} \mathrm{~Pb}}{{ }^{204} \mathrm{~Pb}} c$ & $\begin{array}{l}\text { Total common } \\
\mathrm{Pb}(\mathrm{pg})\end{array}$ & ${ }^{208} \mathrm{~Pb}(\%)^{b}$ & $\begin{array}{l}\frac{{ }^{206} \mathrm{~Pb}}{{ }^{204} \mathrm{U}} \\
( \pm \% 1 \sigma)^{d}\end{array}$ & $\begin{array}{l}\frac{{ }^{207} \mathrm{~Pb}}{{ }^{235} \mathrm{U}} d \\
( \pm \% 1 \sigma)\end{array}$ & $\begin{array}{l}\frac{{ }^{207} \mathrm{~Pb}}{{ }^{206} \mathrm{~Pb}} d \\
( \pm \% 1 \sigma)\end{array}$ & $\begin{array}{l}\frac{{ }^{206} \mathrm{~Pb}}{{ }^{238} \mathrm{U}} \mathrm{age} \\
(\mathrm{Ma} ; \pm \% 2 \sigma)\end{array}$ & $\begin{array}{l}\frac{{ }^{207} \mathrm{~Pb}}{{ }^{206} \mathrm{~Pb}} \text { age } \\
(\mathrm{Ma} ; \pm \% \text { 2 } \sigma)\end{array}$ \\
\hline \multicolumn{13}{|c|}{ Sample 1 (quartz albite syenite stock) } \\
\hline 11 & $\mathrm{~N} 5,+74$ & 0.005 & 2722 & 783 & 472 & 348 & 34.9 & $0.19772(0.12)$ & $2.7024(0.30)$ & $0.09913(0.24)$ & $1163.0(2.5)$ & $1607.8(9.0)$ \\
\hline 12 & $\mathrm{~N} 5,+74$ & 0.006 & 1602 & 455 & 1592 & 79 & 26.6 & $0.22009(0.13)$ & $3.0631(0.16)$ & $0.10094(0.0)$ & $1282.4(3.1)$ & $1641.4(2.8)$ \\
\hline 13 & $\mathrm{~N} 5,+74$ & 0.005 & 1460 & 458 & 4103 & 27 & 24.5 & $0.24993(0.10)$ & $3.5358(0.12)$ & $0.10261(0.05)$ & $1438.1(2.5)$ & $1671.8(1.8)$ \\
\hline 14 & $\mathrm{~N} 5,+74$ & 0.020 & 1472 & 415 & 1078 & 357 & 26.3 & $0.21897(0.36)$ & $3.0483(0.42)$ & $0.10097(0.13)$ & $1276.4(8.4)$ & $1641.9(4.7)$ \\
\hline \multicolumn{13}{|c|}{ Sample 2 (pegmatitic segregations of diorite dike) } \\
\hline 1 & $\mathrm{~N} 5,+134$ & 0.014 & 2607 & 1122 & 6190 & 18 & 33.6 & $0.30000(0.19)$ & $4.3287(0.19)$ & $0.10465(0.02)$ & $1691.3(5.7)$ & 1708.2(0.6) \\
\hline 2 & M5, +134 & 0.020 & 4974 & 2180 & 78020 & 22 & 35.6 & $0.29605(0.25)$ & $4.2723(0.25)$ & $0.10466(0.01)$ & $1671.7(7.2)$ & $1708.4(0.4)$ \\
\hline 3 & M5, +74 & 0.027 & 3997 & 1740 & 117000 & 167 & 35.1 & $0.29659(0.33)$ & $4.2795(0.33)$ & $0.10465(0.02)$ & 1674.4(9.8) & 1708.1(0.6) \\
\hline 4 & $\mathrm{~N} 5,+74$ & 0.021 & 3670 & 1647 & 39170 & 34 & 38.0 & $0.29207(0.26)$ & $4.2122(0.26)$ & $0.10460(0.02)$ & $1651.8(7.6)$ & $1707.3(0.6)$ \\
\hline \multicolumn{13}{|c|}{ Sample 3 (gabbroic stock) } \\
\hline 5 & $\mathrm{~N} 2,+105$ & 0.006 & 5408 & 2423 & 83250 & 7 & 36.3 & $0.29970(0.30)$ & $4.3271(0.30)$ & $0.10472(0.03)$ & $1689.9(8.8)$ & $1709.3(1.0)$ \\
\hline 6 & $\mathrm{~N} 2,+74$ & 0.004 & 5564 & 2439 & 40180 & 10 & 35.3 & $0.29800(0.46)$ & $4.2939(0.46)$ & $0.10451(0.06)$ & $1681.4(13.7)$ & $1705.6(2.3)$ \\
\hline 7 & $\mathrm{~N} 2,+74$ & 0.005 & 3468 & 1491 & 15970 & 19 & 34.4 & $0.29627(0.11)$ & $4.2716(0.17)$ & $0.10457(0.07)$ & $1672.8(3.3)$ & $1706.7(2.7)$ \\
\hline 8 & $\mathrm{~N} 2,+74$ & 0.005 & 2960 & 1334 & 22330 & 12 & 37.0 & $0.29822(0.11)$ & $4.3144(0.12)$ & $0.10493(0.03)$ & $1682.5(3.2)$ & $1713.0(1.2)$ \\
\hline 9 & $\mathrm{~N} 5,+134$ & 0.021 & 2319 & 1095 & 36320 & 25 & 39.9 & $0.29801(0.05)$ & $4.2904(0.05)$ & $0.10442(0.02)$ & $1681.4(1.4)$ & $1704.1(0.5)$ \\
\hline 10 & $\mathrm{~N} 5,+134$ & 0.014 & 2741 & 1347 & 20730 & 34 & 41.3 & $0.30265(0.14)$ & $4.3616(0.14)$ & $0.10452(0.02)$ & $1704.4(4.3)$ & $1705.9(0.7)$ \\
\hline \multicolumn{13}{|c|}{ Sample 4 (diorite clast in Wernecke Breccia) } \\
\hline 15 & $\mathrm{~N} 5,74-134, \mathrm{u}$ & 0.017 & 849 & 265 & 3832 & 48 & 37.5 & $0.20553(0.13)$ & $2.8612(0.21)$ & $0.10097(0.10)$ & $1205.0(2.7)$ & $1641.9(3.9)$ \\
\hline 16 & M5, 44-74, u & 0.050 & 1205 & 293 & 5883 & 111 & 31.4 & $0.17584(0.07)$ & $2.3927(0.07)$ & $0.09869(0.02)$ & $1044.2(1.3)$ & $1599.6(0.9)$ \\
\hline 17 & $\mathrm{~N} 10,44-105, \mathrm{u}$ & 0.073 & 1328 & 263 & 4989 & 166 & 33.8 & $0.13863(0.37)$ & $1.8552(0.37)$ & $0.09706(0.03)$ & $836.9(5.8)$ & $1568.3(1.1)$ \\
\hline 18 & $\mathrm{~N} 10,44-105, \mathrm{u}$ & 0.062 & 856 & 258 & 2203 & 248 & 47.5 & $0.16665(0.08)$ & $2.2507(0.10)$ & $0.09795(0.05)$ & $993.6(1.4)$ & $1585.5(1.9)$ \\
\hline 19 & $\mathrm{~N} 10,44-105, \mathrm{u}$ & 0.057 & 1166 & 300 & 6498 & 112 & 34.5 & $0.17756(0.05)$ & $2.4193(0.06)$ & $0.09882(0.02)$ & 1053.6(0.9) & $1602.0(0.9)$ \\
\hline
\end{tabular}

Note: Zircon concentrates were prepared from $\sim 20 \mathrm{~kg}$ samples using conventional crushing, grinding, Wilfley table, heavy liquids, and Frantz magnetic separator techniques. Only trace amounts $(<0.5 \mathrm{mg})$ of zircon were recovered from each sample. U-Pb analyses were done in the Geochronology Laboratory at the University of British Columbia, Vancouver, B.C. The methodology for zircon grain selection, abrasion, dissolution, geochemical preparation, and mass spectrometry is described in Mortensen et al. (1995). Most zircons were air abraded (Krogh 1982) prior to dissolution to minimize the

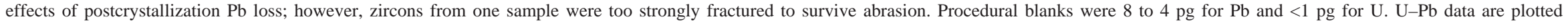
in conventional U-Pb concordia plots in Fig. 5. Errors attached to individual analyses were calculated using the numerical error propagation method of Roddick (1987), and decay constants used are those recommended by Steiger and Jäger (1977). Compositions for initial common Pb were taken from the model of Stacey and Kramers (1975). All errors of ages are given at the 2 $\sigma$ level. Data

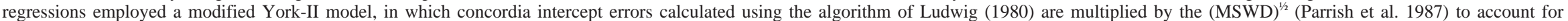
excess scatter about the calculated regression line.

${ }^{a} \mathrm{~N} 1$ and N2, nonmagnetic at given degrees side slope on Frantz isodynamic magnetic separator; u, unabraded. Grain size in $\mu \mathrm{m}$.

${ }^{b}$ Radiogenic $\mathrm{Pb}$, corrected for blank, initial common $\mathrm{Pb}$, and spike.

${ }^{c}$ Corrected for spike and fractionation.

${ }^{d}$ Corrected for blank $\mathrm{Pb}$ and $\mathrm{U}$ and common $\mathrm{Pb}$ 
fractions were analyzed (Table 3). Measured U concentrations are high (2319-5564 ppm); however, the analyses range from concordant to only moderately discordant $(0.1-2.3 \%$ discordant). Four of the analyses give overlapping ${ }^{207} \mathrm{~Pb} /{ }^{206} \mathrm{~Pb}$ ages and appear to have been free of any older inherited zircon component(s); however, two fractions (5 and 8) give slightly older ${ }^{207} \mathrm{~Pb} /{ }^{206} \mathrm{~Pb}$ ages and are interpreted to have contained a minor inherited zircon component (although no visible cores were noted). Fraction 10 is concordant with a ${ }^{207} \mathrm{~Pb} /{ }^{206} \mathrm{~Pb}$ age of $1705.9 \pm 0.7 \mathrm{Ma}$, which is interpreted as the crystallization age of the sample (Fig. 6c). The four inheritance-free grains define a linear array with calculated upper and lower intercepts of $1705.9 \pm 2.0$ and $\sim 182 \mathrm{Ma}$, respectively. The upper intercept is identical within analytical uncertainty to the ${ }^{207} \mathrm{~Pb} /{ }^{206} \mathrm{~Pb}$ age of the concordant fraction, and the lower intercept indicates mainly recent $\mathrm{Pb}$ loss.

Sample 4 is from a rounded megaclast of fine-grained diorite ( $2 \mathrm{~m}$ diameter) in a large zone of Wernecke Breccia within the Gillespie Lake Group. The breccia zone, which is $5 \mathrm{~km}$ long and up to $2 \mathrm{~km}$ wide, hosts many megaclasts of diorite (up to $750 \mathrm{~m} \mathrm{long}$ ), and at least two megaclasts of anorthosite. The dioritic clasts were probably torn from a nearby, similar intrusion that crosscut the Gillespie Lake Group (Thorkelson 2000) and then dispersed and rounded during breccia transport.

Only a trace amount $(<100 \mu \mathrm{g})$ of zircon was recovered from sample 4. It consisted of small, highly fractured, poorclarity fragments of originally larger grains. The strongly fractured nature of the grains precluded abrasion of the zircons prior to dissolution. Five fractions were analyzed (Table 3) and are all strongly discordant (29-50\%). The four least discordant analyses, however, define a linear array (MSWD = 2.2) with calculated upper and lower intercepts of $1713.6 \pm 12.7$ and $\sim 266 \mathrm{Ma}$, respectively (Fig. 6d). As with previous samples, the upper intercept is interpreted as the crystallization age of the sample, and the lower intercept indicates relatively recent $\mathrm{Pb}$ loss.

The emplacement ages of the BPRI provide an important new constraint on the depositional age of the Wernecke Supergroup. Three of the dated intrusions (samples 1-3) were emplaced into the lowest part of the Wernecke Supergroup, the Fairchild Lake Group. These intrusions are dated at ca. $1.71 \mathrm{Ga}$, constraining the age of the lower Wernecke Supergroup to ca. $1.71 \mathrm{Ga}$ or older. Are the upper parts of the Wernecke Supergroup also older than this age? Field relations strongly suggest that this is the case. Intrusions that crosscut the upper part of the Wernecke Supergroup, the Gillespie Lake Group, have been mapped as part of the BPRI (Thorkelson 2000). One of these intrusions, which retains part of its intrusive contact with the Gillespie Lake Group, has been dismembered by Wernecke Breccia and is apparently the source for numerous dioritic megaclasts, including sample 4 , dated at ca. $1.71 \mathrm{Ga}$. The conformable and gradational nature of all units in the Wernecke Supergroup (Delaney 1981) and the absence of volcanic strata within the Wernecke Supergroup that could correlate with the BPRI further supports our position that the BPRI were emplaced after the entire Wernecke Supergroup was deposited.

\section{Implications for northwestern Laurentia}

Emplacement of the BPRI marks a continental magmatic episode at ca. $1.71 \mathrm{Ga}$. Extensional tectonism probably caused the magmatism and may have been related to distal plume activity or subduction. This igneous event followed deposition of the $13 \mathrm{~km}$-thick Wernecke Supergroup and preceded widespread emplacement of the hydrothermal Wernecke Breccias at 1.6 Ga (Laznicka and Edwards 1979; Bell 1986; Laznicka and Gaboury 1988; Thorkelson et al. 2001). The Racklan Orogeny also postdated Wernecke Supergroup deposition and preceded Wernecke brecciation, but the timing of Racklan deformation relative to BPRI magmatism remains uncertain.

\section{Correlations}

Constraining the depositional age of the Wernecke Supergroup to $>1.71 \mathrm{Ga}$ has important implications for the Paleoproterozoic to Mesoproterozoic history of ancestral North America (Figs. 6-8). Of primary interest is the preclusion of correlation between the Wernecke Supergroup and the Mesoproterozoic Belt Supergroup, $1800 \mathrm{~km}$ to the south, in southeastern British Columbia and the northwestern United States (Aitken and McMechan 1992; Ross et al. 1992; Link et al. 1993). The lower part of the Belt succession is dated at ca. 1.47 Ga (Höy 1989; Anderson and Davis 1995; Sears et al. 1998), and most of the Belt strata were deposited before ca. 1.40 Ga (Evans et al. 2000). These constraints indicate that the majority of the Belt succession was deposited 240 $310 \mathrm{Ma}$ after the BPRI intruded the Wernecke Supergroup (Fig. 8). Intriguingly, the Belt succession was deposited, in part, on a granitic basement that crystallized at $1577 \mathrm{Ma}$ (Doughty et al. 1998). By the time the first Belt sediments were deposited, the Wernecke Supergroup had been intruded by the BPRI, overlain by the Slab volcanics, twice deformed, and hydrothermally brecciated.

The Muskwa assemblage (Fig. 8), with a possible age range of ca. 1766-779 Ma (Long and Pratt 2000; Ross et al. 2001), is another candidate in the Cordilleran region of North America for correlation with the Wernecke Supergroup (Bell 1968; Aitken and McMechan 1992). The Muskwa is exposed in northern British Columbia, about $700 \mathrm{~km}$ south of the Wernecke Supergroup (Fig. 8). It is stratigraphically dissimilar to the Wernecke Supergroup (Long et al. 1999), and correlations between the two successions have generally not been drawn. On the basis of contrasting populations of detrital zircon ages, correlation of the Muskwa and Belt successions is considered unlikely (Ross et al. 2001).

The predominantly fluvial Hornby Bay Group (Kerans et al. 1981) in the Northwest Territories has also been correlated with the Wernecke Supergroup (e.g., Bowring and Ross 1985). However, the upper part of the Hornby Bay Group contains a volcanic complex dated at $1663 \mathrm{Ma}$ (Bowring and Ross 1985), approximately 60 Ma younger than the minimum age of the Wernecke Supergroup. The volcanics are part of a "syntectonic" assemblage apparently deposited during the Forward Orogeny (Fig. 8), a possible eastward equivalent of the Racklan Orogeny (Cook and MacLean 1995). The lowest parts of the Hornby Bay Group are younger than strike-slip 
Fig. 7. Margin of a small stock of the BPRI composed of quartz albite syenite (light grey). The stock has been fragmented during emplacement of Wernecke Breccia (dark grey). Sample 1 (located in Fig. 2) was taken from a nonbrecciated part of this stock.

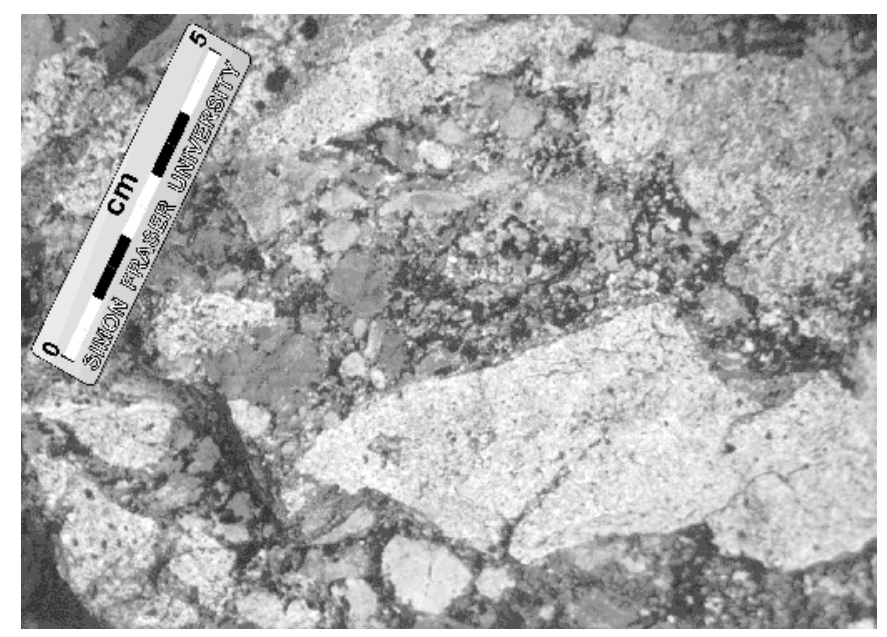

Fig. 8. Time-stratigraphic columns for Paleoproterozoic and early Mesoproterozoic supracrustal rocks in western Canada and the northwestern United States. Maximum possible age ranges are shown for each succession. Orogenic events are circled. Question marks show uncertain age limits. Cop. volc's, Coppermine volcanics; EK, East Kootenay Orogeny; F, Forward Orogeny; R, Racklan Orogeny; Gp., Group. Data and relations from McMechan and Price (1982), Ross et al. (1992), Cook and MacLean (1995), Anderson and Davis (1995), Abbott (1997), Sears et al. (1998), Long and Pratt (2000), Thorkelson (2000), Evans et al. (2000), Ross et al. (2001), and Thorkelson et al. (2001).

\begin{tabular}{|c|c|c|c|c|}
\hline & $\begin{array}{l}\text { Southern } \\
\text { B.C., } \\
\text { Northwest } \\
\text { U.S. } \\
?\end{array}$ & $\begin{array}{l}\text { Northern } \\
\text { B.C. } \\
\text { ??? }\end{array}$ & $\begin{array}{l}\text { Yukon, } \\
\text { Western } \\
\text { N.W.T. } \\
\text { ??? }\end{array}$ & $\begin{array}{l}\text { N.W.T. } \\
\text { @Great } \\
\text { Bear } \\
\text { Lake }\end{array}$ \\
\hline Ma & & \multirow{6}{*}{$\begin{array}{l}\text { Muskwa } \\
\text { assemblage }\end{array}$} & $\begin{array}{l}\text { Pinguicula, } \\
\text { lower }\end{array}$ & Cop. volc's \\
\hline 1300 & $? E K$ & & $\begin{array}{l}\text { Fifteenmile, } \\
\text { lower Mack- } \\
\text { enzie Mtns. } \\
\text { Hart R. volc's }\end{array}$ & \multirow{4}{*}{$\begin{array}{l}\text { Dismal } \\
\text { Lakes } \\
\text { Group }\end{array}$} \\
\hline 1400 & $\begin{array}{c}\text { Belt } \\
\text { Supergroup }\end{array}$ & & \multirow{5}{*}{$\begin{array}{l}\text { Wernecke } \\
\text { Super- } \\
\text { group }\end{array}$} & \\
\hline 1500 & & & & \\
\hline 1600 & & & & \\
\hline 1700 & & & & $\begin{array}{l}\text { Hornby }(F) \\
\text { Bay Gp. }\end{array}$ \\
\hline 1800 & & BPRI & & \\
\hline
\end{tabular}

faults that may have been formed at the same time as ca. 1735 Ma strike-slip faulting and metamorphism along the southeastern margin of the Slave Province (Henderson et al. 1990). These relations indicate that only the lower parts of the Hornby Bay Group may be time-equivalent to the Wernecke Supergroup. For Wernecke - Hornby Bay correlation to be correct, one of two possibilities seems necessary. First, a major unconformity could exist within the Hornby Bay Group. Although such a feature has not yet been recognized, it would permit units of the Hornby Bay Group beneath the syntectonic unit to be older than $1.71 \mathrm{Ga}$ and to correlate with the Wernecke Supergroup. Second, deposition of the Wernecke Supergroup - Hornby Bay Group could have been diachronous, with younger strata transgressing easterly over the Laurentian craton. In this situation, the Hornby Bay Group would be correlative, but not timeequivalent, with the Wernecke Supergroup. In this model, however, continued sedimentation in the Wernecke basin might be expected throughout the interval of Hornby Bay deposition, a scenario for which there is no evidence in the rock record. Thus, correlations between the Hornby Bay and Wernecke successions, although possible, remain problematic and appear unlikely.

\section{Tectonic significance}

The Wernecke Supergroup represents development of the first major supracrustal basin in northwestern Laurentia following regional cratonization at ca. 1.85 Ga (Hoffman 1989; Villeneuve et al. 1991; Ross et al. 1991). The great thickness of the Wernecke Supergroup ( $13 \mathrm{~km}$; Delaney 1981; Thorkelson 2000) implies basin formation by crustal extension, thinning, and thermal subsidence. Two clastic to carbonate grand cycles infer two stages of basin subsidence (Delaney 1981). Paleocurrents were interpreted by Delaney (1981) as evidence for sediment derivation from the north, i.e., from northern Laurentia, but the possibility of sediment contribution from a southern source seems plausible because reversely directed paleocurrents are abundant (Delaney 1981). Whether the Wernecke basin represents development of a passive margin or an aulocogenic depression within a continental platform is not certain. The southern and western margins of the Wernecke basin are not exposed. They were probably separated from the northern and eastern basin margins during continental breakup and may be located on another continent.

If the Wernecke basin developed as an intracratonic basin, as the younger Belt basin appears to have done (Ross et al. 1992; Link et al. 1993), then it could signify an event of aborted rifting and modest attenuation of continental crust. If, however, genesis of the Wernecke basin resulted in the formation of a passive margin, then the northwestern part of Laurentia, perhaps extending from northern Yukon to northern British Columbia, could have become detached from another landmass. Although the Muskwa basin (Figs. 8, 9), of poorly constrained Paleoproterozoic to Mesoproterozoic age, could have formed during an unrelated event of extension, it alternatively could have developed in the same rift system as the Wernecke basin, and the combined Wernecke-Muskwa rift system could have extended through central British Columbia. Farther south, candidates for a Paleoproterozoic rift assemblage 
Fig. 9. Schematic continental configuration between Australia and Laurentia at 1.6 Ga (after Moores 1991). Shape of conjugate coastlines taken from Karlstrom et al. (1999) and Burrett and Berry (2000). Reconstruction is based on correlation of the BPRI and the Wernecke Breccias with coeval rocks in Australia. Antarctica (not shown) is generally thought to have lain alongside Laurentia, in contact with southern Australia, but the position of the paired Australia-Antarctica landmass relative to Laurentia is controversial. Names of the main basins and inliers formed largely in the interval 1.85-1.3 Ga are as follows: 1, Wernecke, Pinguicula, Fifteenmile, Mackenzie Mountains, Hornby Bay, and Dismal Lakes; 2, Muskwa; 3, Belt and Purcell; 4, Athabasca; 5, Thelon; 6, Georgetown and Coen; 7, Mount Isa, MacArthur, and Pine Creek; 8, Tennant Creek, Arunta, Amadeus, and Musgrave; 9, Glengarry; 10, Gawler Range and Pandurra. Basin dimensions are exaggerations of actual regions of outcrop.

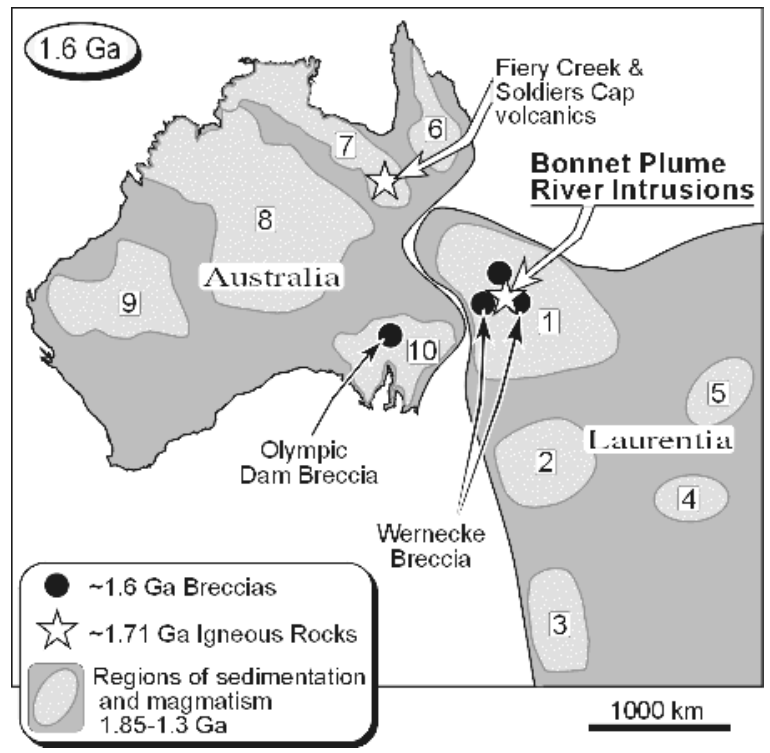

are not present, inferring that any separation of another landmass from southern British Columbia and the western United States must have been minor at this time.

The Racklan Orogeny inverted the Wernecke basin in Paleoproterozoic time (Figs. 3, 8; Thorkelson et al. 2001). Deformation was thin-skinned everywhere (Cook 1992; Dredge Mitchelmore and Cook 1994), except in the Northwest Territories where the possibly equivalent Forward Orogeny (Cook and MacLean 1995) produced Laramide-type uplifts. The orogeny is associated with neither arc volcanism nor subduction-related metamorphism and appears to have produced only moderate crustal thickening. The absence of a proximal source for compressional stress in the Wernecke basin implies that far-field stresses from intense collision zones may have been responsible for basin collapse. The Wernecke basin would have been a zone of weakness, by virtue of its attenuated crustal infrastructure, in an otherwise strong craton, and could have been preferentially strained during an interval of compression. Arguments of this type have been made for the Paleozoic Illinois Basin of the north-central United States, which was folded and faulted along with basement remobilization during mid-Paleozoic Appalachian orogenesis (McBride 1998).

Could far-field stresses have been transferred northwestward to the Wernecke basin from Paleoproterozoic orogenies in southwestern Laurentia? Four orogenic events in the southwestern United States, including the Yavapai and Mazatzal orogenies, record accretion of juvenile arc terranes to the southern margin of Laurentia from 1780 to $1650 \mathrm{Ma}$ (Condie 1992; Van Schmus et al. 1993). Subduction as a process of the terrane accretions is implied by near-identical ages of terrane formation and collision. The intensity of the collisions was high, as indicated by locally high metamorphic grades and widespread syn- to postcollisional magmatism. The timing of these collisions makes them attractive as a source of compression for Racklan Orogeny, which is bracketed between the end of Wernecke Supergroup deposition $(\geq 1.71$ $\mathrm{Ga})$ and the onset of Wernecke brecciation (1.6 Ga). Additional work on the contacts between Racklan-generated schists and the BPRI will more tightly constrain the timing of Racklan deformation and may indicate which of the orogenies in southwestern Laurentia are most suitably linked to the Racklan Orogeny.

\section{Continental considerations}

Information on the BPRI along with other recent findings (Fig. 3) provide constraints on the restoration of Laurentia with other Precambrian continents. As noted in reviews by Ross (1991), Gabrielse and Campbell (1992), and Link et al. (1993), western North America underwent a Cordilleranlong extensional event in the Neoproterozoic marked by deposition of the Windermere Supergroup, its stratigraphic equivalents, and concomitant igneous rocks. Along with subsequent extension in the early Paleozoic (Bond and Kominz 1984), the Windermere event is generally regarded as an interval of continental rifting and separation by sea-floor spreading.

Three main candidates for the separated continental landmass include (i) Siberia (Sears and Price 1978, 2000); (ii) Australia (Eisbacher 1985; Bell and Jefferson 1987), possibly coupled with east Antarctica (Moores 1991; Dalziel 1991; Hoffman 1991); and (iii) south China ( $\mathrm{Li}$ et al. 1995). The south China option appears to have validity based on Neoproterozoic rocks, but is not considered further in this discussion because linkages of Paleoproterozoic to Mesoproterozoic age have not been recognized. Similarly, the Siberian "connection" may have relevance to genesis of the Belt basin and other features in west-central Laurentia, but the Siberian landmass in this reconstruction does not extend far enough to the north to be juxtaposed with rocks of northern British Columbia and the Yukon.

Australia as a conjugate landmass to Laurentia has been explored in greatest detail, and three general positions of Australia have been proposed. The southwest United States east Antarctica (SWEAT) configuration of Moores (1991) and later workers aligns northeastern Australia with northwestern Laurentia (Fig. 9). The configurations of Karlstrom et al. (1999) and Burrett and Berry (2000) place Australia far to the south, leaving northwestern Laurentia without a cratonal counterpart. In the configuration of Ross et al. (1992) and the inferred position of Doughty et al. (1998), Australia is placed in an intermediate position, but still too far south to be directly relevant to the Paleoproterozoic and Mesoproterozoic history of the Yukon. Thus, only in the 
SWEAT option is northwestern Laurentia juxtaposed with an identified conjugate landmass.

If eastern Australia and northwestern Laurentia were connected in the Early Proterozoic, their conjuncture occurred, most plausibly, during the 1.95-1.84 Ga Wopmay Orogeny in Canada and the concurrent Barramundi Orogeny in Australia (Hoffman 1989; Solomon and Groves 1994). This possibility is supported by the similar shapes of apparent polar wander paths from Australia and North America, from the late Paleoproterozoic to the Neoproterozoic (Idnurm and Giddings 1995). Igneous rocks in Australia, which may correlate with the BPRI $(1710 \pm 6 \mathrm{Ma})$, include the Fiery Creek Volcanics (1709 $\pm 3 \mathrm{Ma}$ ) and older parts of the Soldiers Cap Group (1712 $\pm 6 \mathrm{Ma}$ ) in the Mount Isa inlier (Page and Sun 1998). Another possible linkage exists between the Olympic Dam breccias of South Australia and the Wernecke Breccias in the Yukon (Bell 1982) that were produced by massive surges of Fe-rich hydrothermal fluids (Figs. 3, 9). These breccias are both dated at $1.6 \mathrm{Ga}$ (Thorkelson et al. 2001) and share an iron-oxide-Cu-Au metallogenetic signature (Hitzman et al. 1992).

Laurentia and Australia also host a number of broadly similar intracontinental "rift" basins of post-Wopmay-Barramundi age (Fig. 8). Rocks of "rift sequence 2" in the Mount Isa inlier, particularly the Quilalar and Mary Kathleen successions, are possibly correlative with the ca. 1.84-1.71 Ga Wernecke Supergroup of the Yukon. Other Paleoproterozoic to Mesoproterozoic successions in the Mount Isa and adjacent areas may be correlative with the Muskwa, Pinguicula, and related strata of northwestern Laurentia. Late Mesoproterozoic and Neoproterozoic successions have resulted in more detailed cross-continental correlations. In particular, strata in western and southern Australia have been correlated with strata of the Windermere Supergroup and "Sequence B" (Grenville-age) sedimentary deposits of northern and western Laurentia (Eisbacher 1985; Bell and Jefferson 1987; Young 1995; Rainbird et al. 1996, 1997).

Lastly, we offer the pre-1.6 Ga Racklan Orogeny as a possible linkage with eastern Australia. The source of compression leading to inversion of the Wernecke basin during the Racklan Orogeny is unknown, but could be related to farfield stresses from distant collisions. The cryptic nature of the Racklan event is shared by several collapsed rift basins in Australia, such as those in the Mount Isa, Tennant Creek, Pine Creek, and Stuart Shelf inliers (Fig. 9). In all of these regions, which are inland from recognized collisional or accretionary plate margins of Early to Middle Proterozoic age, basins deposited after ca. 1850 Ma experienced contraction at least once during the interval 1700-1500 Ma. For example, the Isan Orogeny deformed "rift cover" sequences in the Mount Isa inlier between approximately 1620 and $1520 \mathrm{Ma}$ (Solomon and Groves 1994; Page and Sun 1998). The earlier history of the Isan Orogeny (>1600 Ma) could have occurred at the same time as the Racklan Orogeny in Laurentia. The later stages of the Kimban Orogeny in South Australia (ca. 1845-1710; Parker et al. 1993) could also be time-equivalent to the Racklan. The lack of recognized arc magmatism or subduction complexes of Racklan age on the proposed conjugate margins of both continents suggests that, if Australia is the missing western counterpart to Laurentia, the Racklan Orogeny was not involved with consumption of oceanic crust between the two continents. Rather, it was generated by telescoping of a minor seaway floored by attenuated continental crust. In this scenario, the Wernecke basin is preferably regarded as an intracratonic basin, rather than a passive margin, and the Racklan Orogeny resulted from compression transmitted from a distant source into a thin, weak region of crust. Conceivably, compression from accretionary tectonics in the Yavapai-Mazatzal belt of southern Laurentia, transferred through Laurentia and perhaps also Australia, may have been the cause of the Racklan Orogeny and similar-aged events in Australia.

\section{Conclusions}

The BPRI were derived mainly from anatexis of mantle and were probably affected to variable degrees by assimilation of evolved continental crust. The intrusions were emplaced over a narrow interval of time, ca. $1710 \pm 6 \mathrm{Ma}$, into the Wernecke Supergroup of the northern Yukon, probably during an event of lithospheric extension. The intrusions have been largely dismembered and altered by surges of hydrothermal fluids. The age of the intrusions constrains the depositional age of the Wernecke Supergroup to $>1.71$ Ga (Early Proterozoic) and precludes correlation of those strata with the Belt Supergroup and other Middle Proterozoic successions.

The BPRI are very close in age to some late Paleoproterozoic igneous rocks in the Mount Isa inlier of Australia. This similarity is one of several that may be drawn between northwestern Laurentia and Australia, suggesting that the two continents may have been joined to one another from Paleoproterozoic through Neoproterozoic time, beginning with suturing during the Wopmay and Barramundi orogenies at ca. $1.9 \mathrm{Ga}$; continuing with intracratonic Wernecke basin formation, Racklan orogenesis, and BPRI magmatism, all prior to $1.6 \mathrm{Ga}$; and ending with Neoproterozoic to early Paleozoic rifting and sea-floor spreading. The proposed linkages support not only the SWEAT model of Moores (1991), which focuses on Neoproterozoic connections, but also the paleomagnetic model of Idnurm and Giddings (1995), which favours continental union from late Paleoproterozoic to the Neoproterozoic. Collapse of the Wernecke basin, and other depocentres in Australia and Laurentia, may have been caused by far-field stresses transmitted from distant collisional orogens and focussed by weaknesses in crustal infrastructure inherited during basin formation. In this way, the Yavapai, Mazatzal, and associated collisional events in southern Laurentia may be tectonically related to Racklan orogenesis in northwestern Laurentia and to magmatism and deformation in Australia.

\section{Acknowledgments}

Funding was provided by the Yukon Geology Program, Lithoprobe, the Natural Sciences and Engineering Research Council of Canada, and the Australian Research Council fellowship scheme. Don Francis and Gerry Ross are thanked for constructive reviews. 


\section{References}

Abbott, J.G. 1997. Geology of the upper Hart River Area, eastern Ogilvie Mountains, Yukon Territory (116 A/10, 116 A/11). Exploration and Geological Services Division, Yukon, Indian and Northern Affairs Canada, Bulletin 9.

Aitken, J.D., and McMechan, M.E. 1992. Middle Proterozoic assemblages. In Geology of the Cordilleran Orogen in Canada. Edited by H. Gabrielse and C.J. Yorath. Geological Survey of Canada, Geology of Canada, No. 4, Chap. 5, pp. 97-124. (Also Geological Society of America, The Geology of North America, Vol. G-2.)

Anderson, H.E., and Davis, D.W. 1995. U-Pb geochronology of the Moyie sills, Purcell Supergroup, southeastern British Columbia: implications for the Mesoproterozoic geological history of the Purcell (Belt) basin. Canadian Journal of Earth Sciences, 32: 1180-1193.

Bell, R.T. 1968. Proterozoic stratigraphy of northeastern British Columbia. Geological Survey of Canada, Paper 67-68.

Bell, R.T. 1982. Comments on the geology and uraniferous mineral occurrences of the Wernecke Mountains, Yukon and District of Mackenzie. In Current research, part B. Geological Survey of Canada, Paper 82-1B, pp. 279-284.

Bell, R.T. 1986. Megabreccias in northeastern Wernecke Mountains, Yukon Territory. In Current research, part A. Geological Survey of Canada, Paper 1986-1A, pp. 375-384.

Bell, R.T., and Jefferson, C.W. 1987. A hypothesis for an Australian-Canadian connection in the late Proterozoic and the birth of the Pacific Ocean. In Proceedings of the Pacific Rim Congress '87, Parkville, Victoria, Australia. Australasian Institute of Mining and Metallurgy, Carlton, Victoria, Australia, pp. 39-50.

Bond, G.C., and Kominz, M.A. 1984. Evidence for thermal subsidence and eustatic sea level change from the Lower Paleozoic miogeocline in western North America. Geological Society of America Bulletin, 95: 155-173.

Bowring, S.A., and Ross, G.M. 1985. Geochronology of the Narakay Volcanic Complex: implications for the age of the Coppermine Homocline and Mackenzie igneous events. Canadian Journal of Earth Sciences, 22: 774-781.

Burrett, C., and Berry, R. 2000. Proterozoic Australia - western United States (AUSWUS) fit between Laurentia and Australia. Geology, 28: 103-106.

Condie, K.C. 1992. Proterozoic terranes and continental accretion in southwestern North America. In Proterozoic crustal evolution. Edited by K.C. Condie. Developments in Precambrian Geology 10, Elsevier, Amsterdam, pp. 447-480.

Cook, F.A. 1992. Racklan Orogen. Canadian Journal of Earth Sciences, 29: 2490-2496.

Cook, D.G., and MacLean, B.C. 1995. The intracratonic Paleoproterozoic Forward orogeny, and implications for regional correlations, Northwest Territories, Canada. Canadian Journal of Earth Sciences, 32: 1991-2008.

Creaser, R.A., Erdmer, P., Stevens, R.A., and Grant, S.L. 1997. Tectonic affinity of Nisutlin and Anvil assemblage strata from the Teslin tectonic zone, northern Canadian Cordillera: constraints from neodymium isotope and geochemical evidence. Tectonics, 16: $107-121$

Dalziel, I.W.D. 1991. Pacific margins of Laurentia and East Antarctica - Australia as a conjugate rift pair: evidence and implications for an Eocambrian supercontinent. Geology, 19: 598-601.

Dalziel, I.W.D. 1997. Overview: Neoproterozoic-Paleozoic geography and tectonics: review, hypothesis, environmental speculations. Geological Society of America Bulletin, 109: 16-42.
Delaney, G.D. 1981. The mid-Proterozoic Wernecke Supergroup, Wernecke Mountains, Yukon Territory. In Proterozoic basins of Canada. Edited by F.H.A. Campbell. Geological Survey of Canada, Paper 81-10, pp. 1-23.

Doughty, P.T., Price, R.A., and Parrish, R.R. 1998. Geology and $\mathrm{U}-\mathrm{Pb}$ geochronology of Archean basement and Proterozoic cover in the Priest River complex, northwestern United States, and their implications for Cordilleran structure and Precambrian continent reconstructions. Canadian Journal of Earth Sciences, 35: $39-54$

Dredge Mitchelmore, M., and Cook, F.A. 1994. Inversion of the Proterozoic Wernecke basin during tectonic development of the Racklan Orogen, northwest Canada. Canadian Journal of Earth Sciences, 31: 447-457.

Eisbacher, G.H. 1981. Sedimentary tectonics and glacial record in the Windermere Supergroup, Mackenzie Mountains, northwestern Canada. Geological Survey of Canada, Paper 80-27.

Eisbacher, G.H. 1985. Late Proterozoic rifting, glacial sedimentation, and sedimentary cycles in the light of Windermere deposition, western Canada. Palaeogeography, Palaeoclimatology, Palaeoecology, 51: 231-254.

Evans, K.V., Aleinikoff, J.N., Obradovich, J.D., and Fanning, C.M. 2000. SHRIMP U-Pb geochronology of volcanic rocks, Belt Supergroup, western Montana: evidence for rapid deposition of sedimentary strata. Canadian Journal of Earth Sciences, 37: 1287-1300.

Gabrielse, H. 1967. Tectonic evolution of the northern Canadian Cordillera. Canadian Journal of Earth Sciences, 4: 271-298.

Gabrielse, H., and Campbell, R.B. 1992. Upper Proterozoic assemblages. In Geology of the Cordilleran Orogen in Canada. Edited by H. Gabrielse and C.J. Yorath. Geological Survey of Canada, Geology of Canada, No. 4, Chap. 6, pp. 127-150. (Also Geological Society of America, The Geology of North America, Vol. G-2.)

Gill, J.B. 1981. Orogenic andesites and plate tectonics. SpringerVerlag, Berlin.

Henderson, J.B., McGrath, P.H., Theriault, R.J., and van Breemen, O. 1990. Intracratonic indentation of the Archean Slave Province into the Early Proterozoic Thelon Tectonic Zone of the Churchill Province, northwestern Canadian Shield. Canadian Journal of Earth Sciences, 27: 1699-1713.

Hitzman, M.W., Oreskes, N., and Einaudi, M.T. 1992. Geological characteristics and tectonic setting of Proterozoic iron oxide $(\mathrm{Cu}-\mathrm{U}-\mathrm{Au}-\mathrm{REE})$ deposits. In Precambrian metallogeny related to plate tectonics. Edited by G. Gall and K. Schulz. Precambrian Research, 58: 241-287.

Hoffman, P.F. 1989. Precambrian geology and tectonic history of North America. In The geology of North America - an overview. Edited by A.W. Bally and A.R. Palmer. Geological Society of America, The Geology of North America, Vol. A, pp. 447-512.

Hoffman, P.F. 1991. Did the breakout of Laurentia turn Gondwanaland inside out? Science (Washington, D.C.), 252: 1409-1412.

Höy, T. 1989. The age, chemistry, and tectonic setting of the Middle Proterozoic Moyie sills, Purcell Supergroup, southeastern British Columbia. Canadian Journal of Earth Sciences, 26: 2305-2317.

Idnurm, M., and Giddings, J.W. 1995. PaleoproterozoicNeoproterozoic North America - Australia link: new evidence from paleomagnetism. Geology, 23: 149-152.

Karlstrom, K.E., Harlan, S.S., Williams, M.L., McLelland, J., Geissman, J.W., and Ahall, K.-I. 1999. Refining Rodinia: geological evidence for the Australia - western U.S. connection in the Proterozoic. GSA Today, 9(10): 1-6.

Kerans, C., Ross, G.M., Donaldson, J.A., and Geldsetzer, H.J. 1981. Tectonism and depositional history of the Helikian Hornby Bay and Dismal Lakes groups, District of Mackenzie. In 
Proterozoic basins of Canada. Edited by F.H.A. Campbell. Geological Survey of Canada, Paper 81-10, pp. 157-182.

Krogh, T.E. 1982. Improved accuracy of U-Pb zircon ages by the creation of more concordant systems using an air abrasion technique. Geochimica et Cosmochimica Acta, 46: 637-649.

Laznicka, P., and Edwards, R.J. 1979. Dolores Creek, Yukon - a disseminated copper mineralization in sodic metasomatites. Economic Geology, 74: 1352-1370.

Laznicka, P., and Gaboury, D. 1988. Wernecke breccias and Fe, $\mathrm{Cu}$, U mineralization: Quartet Mountain - Igor area (NTS $106 \mathrm{E}$ ). In Yukon geology. Vol. 2. Exploration and Geological Services Division, Yukon, Indian and Northern Affairs Canada, pp. 42-50.

Li, Z.-X., Zhang, L., and Powell, C. 1995. South China in Rodinia: part of the missing link between Australia - east Antarctica and Laurentia? Geology, 23: 407-410.

Link, P.K., Christie-Blick, N., Devlin, W.J. et al. 1993. Middle and Late Proterozoic stratified rocks of the western U.S. Cordillera, Colorado Plateau, and Basin and Range province. In Precambrian: conterminous U.S. Edited by J.C. Reed, Jr., Bickford, M.E., Houston, R.S. et al. Geological Society of America, The Geology of North America, Vol. C-2, pp. 463-595.

Long, D.G.F., and Pratt, B.R. 2000. Mesoproterozoic evolution of northeastern British Columbia. In Slave - Northern Cordilleran Cordilleran Lithospheric Evolution (SNORCLE) Transect and Cordilleran Tectonics Workshop Meeting. Edited by F. Cook and P. Erdmer. University of Calgary, Calgary, Alta., Lithoprobe Report 72, pp. 91-92.

Long, D.G.F., Devaney, J.R., and Pratt, B.R. 1999. Tectonostratigraphic framework of the Mesoproterozoic Muskwa Assemblage, northern British Columbia. In Slave - Northern Cordilleran Cordilleran Lithospheric Evolution (SNORCLE) Transect and Cordilleran Tectonics Workshop Meeting. Edited by F. Cook and P. Erdmer. University of Calgary, Calgary, Alta., Lithoprobe Report 69, pp. 112-119.

Ludwig, K.R. 1980. Calculation of uncertainties of U-Pb isotopic data. Earth and Planetary Science Letters, 46: 212-220.

McBride, J.H. 1998. Understanding basement tectonics of an interior cratonic basin; southern Illinois Basin, USA. Tectonophysics, 293: 1-20.

McMechan, M.E., and Price, R.A. 1982. Superimposed low-grade metamorphism in the Mount Fisher area, southeastern British Columbia-implications for the East Kootenay orogeny. Canadian Journal of Earth Sciences, 19: 476-489.

Miyashiro, A. 1974. Volcanic rock series in island arcs and active continental margins. American Journal of Science, 274: 321-355.

Moores, E.M. 1991. Southwest U.S. - East Antarctic (SWEAT) connection: a hypothesis. Geology, 19: 425-428.

Mortensen, J.K., Ghosh, D., and Ferri, F. 1995. U-Pb age constraints of intrusive rocks associated with copper-gold porphyry deposits in the Canadian Cordillera. In Porphyry deposits of the northwestern Cordillera of North America. Edited by T.G. Schroeter. Canadian Institute of Mining and Metallurgy, Special Vol. 46, pp. 142-158.

Norris, D.K., and Dyke, L.D. 1997. Proterozoic. In The geology, mineral and hydrocarbon potential of northern Yukon Territory and northwestern District of Mackenzie. Chap. 4. Edited by D.K. Norris. Geological Survey of Canada, Bulletin 422, pp. $65-84$.

Page, R.W., and Sun, S-S. 1998. Aspects of geochronology and crustal evolution in the Eastern Fold Belt, Mt. Isa Inlier. Australian Journal of Earth Sciences, 45: 343-361.

Parker, A.J., Daly, S.J., Flint, D.I., Flint, R.B., Preiss, W.V., and Teale, G.S. 1993. Paleoproterozoic. In The Precambrian. Edited by J.F. Drexel, W.V. Preiss, and A.J. Parker. Mines and Energy of South Australia, The Geology of South Australia, Vol. 1, pp. 51-105.

Parrish, R.R., Roddick, J.C., Loveridge, W.D., and Sullivan, R.W. 1987. Uranium-lead analytical techniques at the geochronology laboratory, Geological Survey of Canada. In Radiogenic age and isotopic studies, Report 1. Geological Survey of Canada, Paper 87-2, pp. 3-7.

Rainbird, R.H., Jefferson, C.W., and Young, G.M. 1996. The early Neoproterozoic sedimentary Succession B of northwestern Laurentia: correlations and paleogeographic significance. Geological Society of America Bulletin, 108: 454-470.

Rainbird, R.H., McNicoll, V.J., Theriault, R.J., Heaman, L.M., Abbott, J.G., Long, D.G.F., and Thorkelson, D.J. 1997. Pancontinental river system draining Grenville orogen recorded by $\mathrm{U}-\mathrm{Pb}$ and $\mathrm{Sm}-\mathrm{Nd}$ geochronology of Neoproterozoic quartzites and mudrocks, northwestern Canada. Journal of Geology, 105: 117.

Roddick, J.C. 1987. Generalized numerical error analysis with application to geochronology and thermodynamics. Geochimica et Cosmochimica Acta, 51: 2129-2135.

Rogers, J.J.W. 1996. A history of continents in the past three billion years. Journal of Geology, 104: 91-107.

Roots, C.F., and Thompson, R.I. 1988. Long-lived basement weak zones and their role in extensional magmatism in the Ogilvie Mountains, Yukon Territory. In Proceedings of the International Conference on Basement Tectonics. Edited by M.J. Bartholomew, D.W. Hyndman, D.W. Mogk, and R. Mason. Basement Tectonics Committee, Vol. 8, pp. 359-372.

Ross, G.M. 1991. Tectonic setting of the Windermere Supergroup revisited. Geology, 19: 1125-1128.

Ross, G.M., and Villeneuve, M.E. 1997. U-Pb geochronology of stranger stones in Neoproterozoic diamictites, Canadian Cordillera: implications for provenance and ages of deposition. In Radiogenic age and isotopic studies, Report 10. Geological Survey of Canada, Current Research 1997-F, pp. 141-155.

Ross, G.M., Parrish, R.R., Villeneuve, M.E., and Bowring, S.A. 1991. Geophysics and geochronology of the crystalline basement of the Alberta Basin, western Canada. Canadian Journal of Earth Sciences, 28: 512-522.

Ross, G.M., Parrish, R.R., and Winston, D. 1992. Provenance and $\mathrm{U}-\mathrm{Pb}$ geochronology of the Mesoproterozoic Belt Supergroup (northwestern United States): implications for age of deposition and pre-Panthalassa plate reconstructions. Earth and Planetary Science Letters, 113: 57-76.

Ross, G.M., Villeneuve, M.E., and Theriault, R.J. 2001. Isotopic provenance of the lower Muskwa assemblage (Mesoproterozoic, Rocky Mountains, British Columbia): New clues to correlation and source areas. In The Mesoproterozoic earth-ocean system of Rodinia. Edited by J. Bartley and L.C. Kah. Precambrian Research Special Vol. 111, pp. 57-77.

Sears, J.W., and Price, R.A. 1978. The Siberian connection: a case for the Precambrian separation of North American and Siberian cratons. Geology, 6: 267-270.

Sears, J.W., and Price, R.A. 2000. New look at the Siberian connection: no SWEAT. Geology, 28: 423-426.

Sears, J.W., Chamberlain, K.R., and Buckley, S.N. 1998. Structural and $\mathrm{U}-\mathrm{Pb}$ geochronological evidence for $1.47 \mathrm{Ga}$ rifting in the Belt basin, western Montana. Canadian Journal of Earth Sciences, 35: 467-475.

Shervais, J.W. 1982. T-V plots and the petrogenesis of modern and ophiolitic lavas. Earth and Planetary Science Letters, 59: 101-118.

Smith, T.E. 1992. Volcanic rocks of Early Proterozoic greenstone belts. In Proterozoic crustal evolution. Edited by K.C. Condie. 
Developments in Precambrian Geology 10, Elsevier, Amsterdam, pp. 7-55.

Solomon, M., and Groves, D.I. 1994. The geology and origin of Australia's mineral deposits. Oxford University Press, New York.

Stacey, J.S., and Kramers, J.D. 1975. Approximation of terrestrial lead isotope evolution by a two-stage model. Earth and Planetary Science Letters, 26: 207-221.

Steiger, R.H., and Jäger, E. 1977. Subcommission on geochronology: convention on the use of decay constants in geo- and cosmochronology. Earth and Planetary Science Letters, 36: 359-362.

Tarney, J. 1992. Geochemistry and significance of mafic dyke swarms in the Proterozoic. In Proterozoic crustal evolution. Edited by K.C. Condie. Developments in Precambrian Geology 10, Elsevier, Amsterdam, pp. 151-179.

Thompson, R.N., Morrison, M.A., Hendry, G.L., and Parry, S.J. 1984. An assessment of the relative roles of crust and mantle in magma genesis: an elemental approach. Philosophical Transactions of the Royal Society of London, Series A, 310: 549-590.

Thorkelson, D.J. 2000. Geology and mineral occurrences of the Slats Creek, Fairchild Lake and "Dolores Creek" areas, Wernecke Mountains, Yukon Territory (106 D/16, 106 C/13, 106 C/14). Exploration and Geological Services Division, Yukon, Indian and Northern Affairs Canada, Bulletin 10.
Thorkelson, D.J., Mortensen, J.K., Davidson, G.J., Creaser, R.A., Perez, W.A., and Abbott, J.G. 2001. Mesoproterozoic intrusive breccias in Yukon, Canada: the role of hydrothermal systems in reconstructions of North America and Australia. In The Mesoproterozoic earth-ocean system of Rodinia. Edited by J.K. Bartley and L.C. Kah. Precambrian Research Special Vol. 111, pp. 31-56.

Van Schmus, W.R., Bickford, M.E., Anderson, J.L. et al. 1993. Transcontinental Proterozoic provinces. In Precambrian: conterminous U.S. Chap. 4. Edited by J.C. Reed, Jr., Bickford, M.E., Houston, R.S. et al. Geological Society of America, The Geology of North America, Vol. C-2, pp. 171-334.

Villeneuve, M.E., Thériault, R.J., and Ross, G.M. 1991. U-Pb ages and Sm-Nd signature of two subsurface granites from the Fort Simpson magnetic high, northwest Canada. Canadian Journal of Earth Sciences, 28: 1003-1008.

Young, G.M. 1995. Are Neoproterozoic glacial deposits preserved on the margins of Laurentia related to the fragmentation of two supercontinents? Geology, 23: 153-156.

Young, G.M., Jefferson, C.W., Long, D.G.F., Delaney, G.D., and Yeo, G.M. 1979. Middle and Late Proterozoic evolution of the northern Canadian Cordillera and Shield. Geology, 7: 125-128. 